\title{
El gobierno del individuo en el puritanismo: William Ames (1576-1633) ${ }^{1}$
}

\author{
Laura ADRIÁN-LARA
}

Recibido: 13 de mayo de 2011. Aceptado: 9 de agosto de 2011.

\section{RESUMEN}

Para William Ames todo lo que concierne al arte de vivir bien (ars bene vivendi) es un asunto teológico. En su planteamiento la teología tiene dos partes, la fe y la observancia. La observancia vendría a sustituir a la ética en tanto que saber práctico que orienta la acción. A ello dedica su obra Conscience with the Power and Cases Thereof, una obra de casuística que en términos de teoría política puede interpretarse como un manual para enseñarnos a gobernar nuestras vidas. Ames introduce y afianza una comprensión ejecutiva de las facultades que se ejercitan en el foro interno, ese ámbito que Hannah Arendt recuperaría para la reflexión política contemporánea con su obra The Life of the Mind (1978). Con ello pretendemos avanzar en la comprensión de la mentalidad puritana que arraiga en New England. Nuestro trabajo tiene en cuenta el ingrediente ramista y aplica nuevos conceptos de la teoría política como el gobierno del individuo o los espacios públicos internos que dan acceso a una comprensión más honda de la democracia del siglo veintiuno.

\section{PALABRAS CLAVE}

William Ames, Petrus Ramus, gobierno del individuo, voluntad, retórica.

\section{ABSTRACT}

For William Ames everything that has to do with the art of living well (ars bene viven$d i)$ is a theological matter. In his approach theology has two parts: faith and obser-

\footnotetext{
${ }^{1}$ Una versión anterior de este artículo fue presentada en el IX Congreso de la Asociación Española de Ciencia Política y de la Administración (Málaga, septiembre de 2009). La autora agradece los comentarios de Daniel Blanch y de Silvina Vázquez, así como de los demás participantes en el grupo "El desafío democrático de la retórica". También agradece la labor de los evaluadores anónimos y de los editores de Foro Interno; han sido una ayuda excepcional para mejorar este trabajo. Cualquier descuido o error es solo responsabilidad de su autora.
} 
vance. Observance replaces ethics as the practical aspect of understanding that orients our actions. This is the subject of his book, Conscience with the Power and Cases Thereof, a casuistic work which can be seen in political theory terms as a manual on how to govern our own lives. Ames introduces and establishes an executive understanding of the faculties that are at work in the internal forum (foro interno), that realm which Hannah Arendt recovered for contemporary political thought through The Life of the Mind (1978). In the following article an analysis is offered of the puritan mentality that became deeply rooted in New England. This study takes into account the influence of Ramism and applies new political theory concepts such as the governance of the individual and internal political spaces, which give access to a more profound understanding of democracy in the twenty-first century.

\section{KEY WORDS}

William Ames, Petrus Ramus, governance of the individual, will, rhetoric.

Che parlo, ahi, che vaneggio? Misera, ohimè, che chieggio?

O Teseo, o Teseo mio, non son, non son quell'io, non son quell'io che i feri detti sciolse: parlò l'affanno mio, parlò il dolore; parlò la lingua sì, ma non gì̀ il core ${ }^{2}$.

Una noche de octubre de 1633 el río Maas se desbordó e inundó gran parte de la ciudad de Rotterdam. Para entonces William Ames llevaba unos dos meses en la ciudad. Había llegado a finales de verano, tal vez en otoño, siguiendo la petición de la iglesia inglesa de la ciudad liderada por Hugh Peter para trabajar allí como profesor. Ames venía de Franeker, donde había pasado varios años como profesor de la universidad de la ciudad (1622-1633), en la misma época en la que René Descartes frecuentaba sus aulas ${ }^{3}$.

Esa noche su casa quedó anegada por el agua. Al parecer, sin darse cuenta de ello, Ames salió de la cama, "se mojó lo pies y como consecuencia cogió fie-

${ }^{2}$ Claudio Monteverdi, Lamento d'Arianna (1608).

${ }^{3}$ Keith L. Sprunger, The Learned Doctor William Ames; Dutch Backgrounds of English and American Puritanism, University of Illinois Press, Urbana, 1972, p. 80. 
bre" 4 . En pocos días su salud empeoró a pesar de los esfuerzos de los médicos y la enfermedad acabó con su vida "trasladándole de la iglesia militante a la iglesia triunfante", en palabras entusiastas de Matthew Nethenus. ${ }^{5}$. Ames tenía cincuenta y siete años. Terminaba una vida intensa de estudio y militancia que había comenzado en Inglaterra y culminó en los Países Bajos. Nacido en Ipswich en 1576, se formó intelectualmente bajo la influencia de William Perkins (1558-1602) en el Christ's College de Cambridge. Tras varios desencuentros con las autoridades anglicanas, Ames se exilió en los Países Bajos y allí consolidó su liderazgo religioso.

Su inesperada muerte frustró sus planes de viajar a New England, siguiendo la sugerencia de John Winthrop (1588-1649), primer gobernador de la Massachusetts Bay Colony. A pesar de todo, su legado se sentía tan vivo entre los que sí pudieron emprender el viaje al nuevo mundo, que Ames era considerado uno de ellos. Una impresión que recoge Keith Sprunger al escribir que "en todo salvo en tomar el barco hacia allá, Ames pertenece a la historia de Nueva Inglaterra"6.

Sepa, lector, que fue por una distracción particular de la mano del Cielo sobre las intenciones de ese gran hombre, el Dr. William Ames, por lo que ahora no encontramos su nombre entre los primeros en el catálogo de nuestros personajes ilustres de Nueva Inglaterra. Una de las personas más eminentes y juiciosas que jamás vivió en este mundo fue intencionalmente un hombre de Nueva Inglaterra, pero no eventualmente, cuando ese hombre profundo, sublime, sutil, indiscutible, en fin, ese doctor angelical, estaba planeando trasladarse a Nueva Inglaterra; pero

4 "Got his feet wet and was in consequence taken with fever and ague". Matthew NETHENUS, "Introductory Preface in which the story of the life of Master Ames is briefly narrated and the excellence and usefulness of his writings shown", John Jansson, Amsterdam, 1668, translated from Latin into English by Douglas Horton, en Douglas HorTon, William Ames by Matthew Nethenus, Hugo Visscher y Karl Reuter, Harvard Divinity School, Cambridge, 1965, p. 19.

5 "Translating him from the church militant to the church triumphant". Ibidem.

6 "In every way except taking the ship across, Ames belongs to the first history of New England". SPRUNGER, The Learned Doctor William Ames, p. 254. "Although he remained behind, many of the leading lights of Dutch Puritanism travelled to America, bringing the Ames gospel with them. His books were a further word to New England. Ames could have counted, at the least, the following American Puritan friends from England and the Netherlands: John Winthrop..., Hugh Peter...; Thomas Hooker...; John Wilson...; Thomas Parker....and Nathaniel Eaton". [A pesar de que él se quedó atrás, muchas de las eminencias del puritanismo holandés viajaron a América, llevando consigo el evangelio de Ames. Sus libros eran la última palabra para Nueva Inglaterra. Ames podría haber contado con, al menos, los siguientes amigos puritanos Americanos de Inglaterra y los Países Bajos: John Winthrop..., Hugh Peter...; Thomas Hooker...; John Wilson...; Thomas Parker....and Nathaniel Eaton]. Ibidem. 
se lo impidió esa Providencia que después permitió que su viuda, sus hijos ${ }^{7}$, y su biblioteca se trasladaran allí".

Este admirado William Ames, autoridad fundamental para los colonos puritanos, podría haber sido el primer presidente de Harvard College; y de hecho lo fue un alumno suyo de Franeker, Nathaniel Eaton (1610-1674) ${ }^{9}$. Aun sin viajar a América, Ames fue una pieza importante que sirvió de puente entre el viejo y el nuevo mundo. Un puente entre el ramismo y el calvinismo que se gestaron en Francia ${ }^{10}$ y la mentalidad que importaron a la costa este de los futuros Estados Unidos los primeros colonos que emprendieron la travesía a través del Atlántico. Desde Suiza y Francia, el calvinismo y el ramismo irradiaron Europa. Ames se impregnó de ellos en el Christ's College de Cambridge, semillero de maestros puritanos radicales, y los llevó consigo a Franeker, universidad que por su influjo se convirtió en el centro del ramismo holandés ${ }^{11}$.

De esta combinación intelectual, que se convertiría en un sedimento muy influyente de los primeros colleges coloniales, especialmente Harvard y Yale ${ }^{12}$, tenemos testimonio hasta una fecha tan tardía como 1714. Entonces, un joven

${ }^{7} \mathrm{Su}$ viuda y sus hijos se instalaron en Salem, Massachusetts, con la ayuda de Hugh Peter. Lee W. GIBBS, "Introduction", en William AMES, Technometry, translated with Introduction and Commentary by Lee W. Gibbs, University of Pennsylvania Press, 1979, p. 17.

8 "Know, reader, that it was by a particular diversion given the hand of Heaven unto the intentions of that great man, Dr. William Ames, that we don't now find his name among the first in the catalogue of our New-English worthies. One of the most eminent and judicious persons that ever lived in this world, was intentionally a New-England man, though not eventually, when that profound, that sublime, that subtil, that irrefragable, - yea that angelical doctor, was designing to transport himself into New England; but he was hindered by that Providence which afterwards permitted his widow, his children, and his library, to be translated hither". Cotton MATHER, Magnalia Christi Americana, Hartford, 1855, p. 236, citado en GIBBS, "Introduction", p. 17. Las cursivas son originales.

${ }^{9}$ SPRUnGer, The learned doctor William Ames, p. 254.

${ }^{10}$ Curiosamente Jean Calvin (1509-1564) y Pierre de la Ramée (1515-1572) eran de la misma región, Picardía; Calvin nacido en Noyon, y Ramus en Cuts. James Veazie SKaLNIK, Ramus and Reform, University and Church at the End of the Renaissance, Truman State University Press, Kirksville, 2002, p. 29.

${ }^{11}$ SPRUnger, The Learned Doctor William Ames, p. 79.

12 Jan van VLIET, William Ames: Marrow of the Theology and Piety of the Reformed Tradition, Ph. D. Dissertation, University Microfilms International, Ann Arbor, Michigan, 2002, pp. 376-377. Perry Miller, The New England Mind. The Seventeenth Century, Harvard University Press, Cambridge, 1954, pp. 154-180. Samuel Eliot Morison, The Founding of Harvard College (1935), Harvard University Press, Cambridge, 1995, pp. 143, 154, 330-332. 
estudiante nacido en Connecticut, y que jamás había pisado suelo europeo, se graduaba en Yale con una obra que seguía el modelo de la Technometria y se plegaba a la autoridad infalible de su autor, William Ames ${ }^{13}$. Un Ames que seguía la estela de Ramus a través de Alexander Richardson ${ }^{14}$. "Véase acerca de cualquier asunto Medulla Theologiae y Cases of Conscience del Doctor Reverendo William Ames", rezaba rozando la idolatría la tesis $n^{\circ} 1267$ sobre Teología de Samuel Johnson (1696-1772) en este trabajo ${ }^{15}$. Johnson sería más tarde presidente del King's College y renegaría de un pensamiento que ya apenas un año después de firmar esta obra, y tras recibir nuevas influencias de Europa, le parecía lleno de limitaciones ${ }^{16}$.

${ }^{13}$ Samuel Johnson, "Technologia sive Technometria" (1714), en Samuel Johnson, His Career and Writings, edited by Herbert and Carol Schneider with a Foreword by Nicholas Murray Butler, Columbia University Press, New York, 1929, vol. II, pp. 56-186. Norman FIERING, "Samuel Johnson and the Circle of Knowledge": The William and Mary Quarterly, vol. 28, n. ${ }^{\circ} 2$ (1971), pp. 199-236.

${ }^{14}$ Para ubicarse intelectualmente, Johnson incluyó en el prefacio una brevísima historia de la filosofía que indicaba que los orígenes de la sabiduría estaban en las escuelas hebreas y en las escuelas griegas que comenzaron a florecer hacia el año 500 a. C.: "From Greece philosophy was introduced into Italy and thence into Germany, Holland, Spain, France, and England. In these countries not a few of the greatest men were found; for their doctrine was Christian. Among these innumerable men the principal sects were Platonists, Peripatetics, and Eclectics. The leader of the eclectic sect was the great man Ramus, at whose feet, as it were, there followed Richardson and then Ames, the greatest of them, followed him and we follow Ames". [Desde Grecia la filosofía fue introducida en Italia y de ahí a Alemania, Holanda, España, Francia e Inglaterra. En estos países se encontraban no pocos de los mejores hombres; ya que su doctrina era cristiana. Entre estos innumerables hombres las principales sectas eran los platónicos, los peripatéticos y los eclécticos. El líder de la secta de los eclécticos fue el gran Ramus, cuyos pasos, por así decirlo, siguió Richardson y después siguió Ames, el mejor de todos, y nosotros seguimos a Ames]. JoHnson, "Technologia sive Technometria", p. 59.

15 "See about anything D. R. G. Ames in Medulla Theologiae and Cases of Conscience". JoHnson, "Technologia sive Technometria", p. 183.

16 "When I was at College I was taught nothing but to be a conceited coxcomb like those that taught. Indeed we had no books and our ignorance made us think almost out of our own brains as a certain Gent. (Mr. Noyes) of those times used to say was the way". [Cuando estaba en la universidad no me enseñaron nada más que a ser un necio presuntuoso como aquellos que me enseñaban. Encima no teníamos libros y nuestra ignorancia nos hacía pensar casi sin emplear nuestros propios cerebros, como cierto caballero de esa época (Mr. Noyes) solía decirnos que había que hacer". Johnson, "Technologia sive Technometria", p. 57.

Al final del tratado una nota manuscrita suya indica que cuando se cumplía un año de haber acabado esta obra, en 1715, "I was wholly changed to the New Learning". [Me cambié completamente al New Learning]. Ibid., p. 186.

Sobre la figura de Samuel Johnson (que no debe confundirse con el Samuel Johnson inglés, contemporáneo suyo), puede leerse Joseph J. ElLIS, The New England Mind in Transition. Samuel 
Hay peculiaridades en el currículo amesiano de especial importancia porque van a influir en los colonos, y en donde se nos descubre la herencia ramista. Ames concibe la dialéctica como una disciplina de "absoluta necesidad" ${ }^{17}$ y postula el relegamiento como sirvienta de una retórica sin invención, reducida a mero adorno lingüístico que embellece el discurso ${ }^{18}$. La retórica, eso sí, lo hace más agradable y más fácil de comprender, como la miel que endulza un brebaje amargo $^{19}$, o más vivo y punzante, como una espada de doble filo que atraviesa al oyente hasta la médula ${ }^{20}$. Igualmente aporta efectividad para conmover los afectos y excitar la voluntad, pero lo hace sin dar tiempo al entendimiento para ejercer su control. Por ello solo puede revestir los saberes que cuentan ya con las garantías de la lógica, de otra manera se caería en la sofistería ${ }^{21}$.

Junto a ello, la ética y la metafísica del currículo escolástico son sustituidas por la teología ${ }^{22}$. Esta reordenación particular de los saberes está guiada por una

Johnson of Connecticut, 1696-1772, Yale University Press, New Haven and London, 1973. Según su relato, el repudio de Johnson por la cultura colonial se confirmó cuando viajó a Londres a finales de 1722 y se quedó fascinado con un mundo que le parecía mucho más refinado y culto que el que había ido formándose en New England. Ibid., pp. 84-85.

${ }^{17}$ William AMES, Technometry, tesis 23, 24, p. 96.

${ }^{18}$ Ibid., tesis 25, 26, pp. 96-97; tesis 102, 103, p. 109.

19 "Rhetorick is as honey to a Bitter potion, or lace to a garment". Alexander RICHARDSON, "Rhetorical Notes", en The Logicians School-Master, London, 1657, p. 29. Respetamos la ortografía del original.

${ }^{20}$ En sus recomendaciones al predicador, Ames aconseja que la prédica sea "viva y efectiva" ("alive and effective"). "Men are to be pricked to the quick so that they feel individually what the apostle said, namely, that the word of the Lord is a two-edged sword, piercing the inward thoughts and affections and going through to the joining of bones and marrow". [Los hombres deben ser punzados en lo más profundo de modo que sientan individualmente lo que el apóstol dijo, a saber, que la palabra del Señor es una espada de doble filo, que atraviesa los pensamientos y sentimientos internos y llega hasta las articulaciones y la médula]. William AMES, The Marrow of Theology, translated from the Third Latin edition (1629) with an introduction by John D. Eusden, Baker Michigan, Books, 1997, libro I, cap. XXXV, 46, pp. 193-194.

21 "For whereas every thing coming to mind, doth first come to the outward senses, then to the inward senses, and hence to the understanding, \& so to the affections, and last of all to the will. Rhetorick come to the understanding, yet presently, before it can examine it, the affections lay hold of it, and so, tickle the will that it may approve it: and hence it came to be abused, I. with sophistry to the understanding; 2. for tickling of the will". [Ya que mientras cualquier cosa que viene a la mente primero llega a los sentidos externos y después al entendimiento, y de ahí a los sentimientos, y en último lugar a la voluntad. La retórica llega al entendimiento, pero en ese momento, antes de que este pueda examinarlo, los afectos se aferran a ello y atraen a la voluntad a la idea de que puede aprobarlo: y de ahí viene el abuso: I. por medio de la sofistería hacia el entendimiento; 2. por estimular la voluntad]. RiCHARDSON, "Rhetorical Notes", p. 50.

${ }^{22}$ AMES, Technometry, tesis 63, pp. 103-104, 155; tesis 111-116, pp. 112-115. 
visión muy sistemática — las artes se fundan en una idea sobre la acción buena (eupraxia), delineada metódicamente a través de reglas universales ${ }^{23}$ - que, combinada con la rigidez moral, prefigura una mentalidad singular.

Con estos datos parece sugerente acercarse al pensamiento de Ames para entender qué tipo de ciudadano empezó a poblar las tierras sobre las que luego se fundará la democracia americana. En concreto, queremos indagar en una faceta pocas veces aceptada por la teoría política por considerarse una cuestión moral o psicológica, y que sin embargo no es menos política que el gobierno de la ciudad. Nos referimos al gobierno del individuo.

En nuestra opinión, esta mentalidad puritana acentúa la privatización de lo que en la escolástica católica y protestante se llamaba el foro interno ${ }^{24}$, una privatización que explicaría por qué la ciencia política que emerge como ciencia social del tronco de la filosofía moral en las universidades americanas de finales del siglo diecinueve ${ }^{25}$ prescinde de este escalón del gobierno. El hecho de que esta tradición emerja de la descomposición de la tradición retórica puede estar vinculado con esta exclusión. Para un autor esencial de la tradición retórica como el florentino Brunetto Latini (c.1220-1294), el problema de gobernarse (governer li mesme) es un asunto principal para pensar en el gobierno de la ciudad ${ }^{26}$.

23 "Art is the idea of eupraxia or good action, methodically delineated by universal rules". [El arte es la idea de eupraxia o buena acción metódicamente delineada por reglas universales]. AMES, Technometry, tesis 1, p. 93. Lee W. Gibbs señala que eupraxia es el término empleado por Aristóteles en la Ética Nicomáquea al tratar la felicidad (Libro I, 8, 1098b, 20-23). Ibid., p. 132.

${ }^{24}$ Hobbes, por ejemplo, así lo menciona varias veces. Thomas HobBes, Leviathan, ed. by Richard Tuck, Revised Student Edition, Cambridge University Press, Cambridge, 2008, cap. 15, p. 110.

${ }^{25}$ Sobre el origen de la ciencia política y el vínculo entre ciencias sociales y filosofía moral puede leerse: Gladys BRYSON, "The emergence of the Social Sciences from Moral Philosophy": International Journal of Ethics, vol. 42, n. ${ }^{\circ} 3$ (1932); Gladys BRYson, "The Comparable Interest of the Old Moral Philosophy and the Modern Social Sciences": Social Forces, vol. 11, n. ${ }^{\circ} 1$ (1932); Anna Haddow, Political Science in American Colleges and Universities, 1636-1900, Octagon Books, New York, 1969.

${ }^{26}$ Para el autor de Li livres dou tresor, la ciencia política, que se nutre de la retórica y de la ética, es la ciencia más elevada y más noble. Brunetto LATINI, Li Livres dou Tresor, Édition critique par Francis J. Carmody, University of California Press, Berkeley \& Los Angeles, 1948, p. 17; libro II, p. 176. Si las virtudes son las piedras preciosas del tesoro, la ciencia política es el libro de oro de su tratado. Con el libro tercero Latini enseña cómo se gobierna la ciudad y con el libro segundo cómo se gobierna uno a sí mismo. Aunque las ponga bajo apartados distintos (la ética y la política), ambas tareas de gobierno están enlazadas. Cuando quiere resumir sus consejos al gobernante para que no se sienta perdido en su labor, le dice que siga lo que ha expuesto al tratar sobre las virtudes y los vicios. Ibid., libro II, p. 417. Como señala Clément Godbarge: "En su ética, Brunetto Latini afirma que la templanza enseña al ciudadano a gobernarse, habilidad previa para 
Una idea que reverbera en el Quijote $^{27}$ y que también es muy propia de la tradición sefardí de Moisés Maimónides (1135-1204) ${ }^{28}$. En las palabras de Matthew Nethenus, que por otra parte dan testimonio de la buena acogida de las enseñanzas de Ames, resuenan los ecos de esta noción devaluada de la retórica como arte vacío. Nethenus denuncia ácidamente a los predicadores ampulosos y vacíos de conocimientos, que carecen de un verdadero deseo de contribuir a la edificación espiritual de sus oyentes:

La experiencia ha enseñado y aún enseña en muchos lugares que donde esta parte de la teología es descuidada, y la enseñanza teológica se limita a prestar atención a veinte o treinta principios controvertidos o aceptados y explicar y tratar todos los textos de la Biblia al modo trivial, los candidatos para el ministerio sagrado permanecen ajenos no solo a la práctica sino también al entendimiento de la santidad, y predican la palabra de Dios, recitan las oraciones, administran los sacramentos y desempeñan las otras funciones del ministerio sagrado casi de un modo carnal, con frialdad o con una muestra vacía de un conocimiento y una elocuencia vacíos más que de un deseo de edificar a sus oyentes.... ¿Cómo pueden los sermones de esta clase, en los que el Evangelio se predica solo con un conocimiento y un poder espiritual fingidos, volver a los oyentes de las cosas terrenales a las cosas espirituales?... ¿Cómo pueden prepararlos y presentarlos como una virgen pura ante Cristo cuando ellos mismos nunca se han dedicado seriamente a la santidad y son ajenos incluso a su conocimiento? ${ }^{29}$.

gobernar a los otros - “...mieux est il à governer soi que autrui”- y para salvaguardar a la ciudad de la soberbia". Clément GodBARGE, "Brunetto Latini y la reconstrucción del ethos republicano": Foro Interno, vol. 5 (2005), p. 98, nota 47.

27 "El que no sabe gobernarse a sí, ¿cómo sabrá gobernar a otros?". Don Quijote de la Mancha, citado en: Javier RoIz, La recuperación del buen juicio. Teoría política en el siglo XX, Foro Interno, Madrid, 2003, p. 302.

${ }^{28}$ Javier RoIz, Sociedad vigilante y mundo judio en la concepción del estado, Editorial Complutense, Madrid, 2008, pp. 53, 94, 246.

29 "Experience has taught and still teaches in many places that where this part of theology is neglected, and theological teaching is limited to looking at twenty or thirty accepted or controversial principles and explaining and treating every biblical text in the trivial mode, candidates for the sacred ministry remains strangers not only to the practice but to the understanding of godliness, and preach the word of God, recite the prayers, administer the sacraments, and perform the other functions of sacred ministry in an almost carnal way, frigidly, or with an show of empty knowledge and eloquence rather than with a desire for the spiritual edification of their hearers...How can sermons of that character, in which the Gospel is preached with only a pretense of spiritual knowledge and power, turn their hearers from wordly to spiritual things?...How can they make them ready and present them as a pure virgin to Christ when they themselves have never devoted themselves seriously to godliness and are strangers even to the knowledge of it?". NETHENUs, "Introductory Preface", pp. 15-16. 
Por eso será significativo que una autora del siglo veinte como Hannah Arendt, después de tratar la vita activa dedique su última obra a lo que ella llamaba la vida del espiritu (The life of the mind), y que los contemporáneos de William Ames referían con una palabra tan política como foro interno o foro conscientiae. Dada esta convergencia de intereses, no es extraño que los temas que van decantándose en la obra de Arendt, el pensamiento, la voluntad y el juicio, sean también los tópicos que preocuparon a nuestro autor.

Este acercamiento a Ames tal vez nos lleve a entender algunos rasgos del ciudadano que están cristalizando tras la emancipación de Roma y nos permita repensar la importancia que puede tener para la democracia de hoy el atender el mundo interno aprovechando los nuevos aportes de la teoría política que consideran sus "espacios públicos"30.

\section{El PROBLEMA DE GOBERNARSE A UNO MISMO PARA WiLliaM AMES}

Continuando la senda de William Perkins, que había sido su maestro en el Christ's College de Cambridge, William Ames escribió su propia obra de casuística en $1630^{31}$. Al hacerlo afrontaba aún sin decirlo de forma explícita el problema del gobierno del individuo. Y lo hacía acudiendo a la raíz más sensible de este asunto: el mundo interno de cada uno de nosotros.

Hay que tener en cuenta que el mundo interno era un territorio en cuyo tratamiento tenían más experiencia los autores adictos a Roma, especialmente los

${ }^{30}$ Sobre el concepto de "espacios públicos internos", véase Javier RoIz, El experimento moderno, Trotta, Madrid, 1992, cap. 1.

${ }^{31}$ William AmEs, Conscience with the Power and Cases Thereof, London, 1643, To the reader, s/p. Esta obra se publica por primera vez en latín bajo el título De conscientia et eius iure vel casibus (1630). La primera edición en inglés es de 1639, pero no es completa. En este trabajo hemos consultado la segunda edición inglesa, de 1643. Lee W. Gibbs llama la atención sobre la forma en que se tradujo el título del latín al inglés. A su parecer, lo más correcto habría sido que se titulara "Conscience and its Right [that is law] or Cases". GIBBS, "Introduction", p. 11. El origen de este tratado está en las tesis doctorales que William Ames presentó en la Universidad de Franeker el 27 de mayo de 1622 con el título "Disputatio Inauguralis, continens theses de conscientia". "The thirty-eight theses and four corollaries, which eventually were appended to the end of Book One, grew over the years into a substantial volume of over 400 pages - so great was the work of education the conscience". [Las treinta y ocho tesis y cuatro corolarios, que eventualmente fueron añadidos al final del Libro Primero, aumentaron a lo largo de los años hasta llegar a un volumen de unas 400 páginas — así de grande era el trabajo de educar la conciencia-]. SPRUNGER, The Learned Doctor William Ames, p. 154. 
teólogos jesuitas ${ }^{32}$. Una de las intenciones de Ames al escribir esta obra, que se convertiría junto a The Marrow of Theology (1627) en un manual esencial en la formación de los divines de las colonias americanas ${ }^{33}$, es precisamente que los "hijos de Israel" no tuvieran que acudir a los "filisteos" papistas para encontrar respuestas a todas aquellas preguntas que eran ineludibles para cualquiera de ellos $^{34}$.

Ames se da cuenta de lo importante que es cuidar la práctica diaria, estas pequeñas cosas sin las cuales - como sucede con los dedos de los pies o de las manos, sin los que no es posible caminar - no se puede mantener la santidad de una iglesia ${ }^{35}$. Su experiencia en el exilio holandés le había mostrado que las con-

${ }^{32}$ Sprunger, The Learned Doctor William Ames, pp. 155-159. De entre los casuistas jesuitas Sprunger menciona a Juan Azor (1536-1603), Francisco Toledo (1532-1596), Vicent Filliucius (1566-1622) y Martin Azpilcueta (1492-1586). Ibid., p. 156.

33 "The Marrow of Sacred Divinity became the standard textbook for the instruction of the New England clergy throughout the seventeenth century. The favored position in which this work was held by Puritans is reflected in the words of Thomas Goodwin (1600-1680), who said that "next to the Bible, he esteemed Dr. Ames his Marrow of Divinity as the best book of the world"'. [La Médula de la Teología se convirtió en el libro de texto estandar para la formación del clero de Nueva Inglaterra durante el siglo diecisiete. La posición favorecida en que fue tenido este trabajo por los puritanos se refleja en las palabras de Thomas Goodwin (1600-1680), que dijo que "después de la Biblia, apreciaba la Médula de la Teología de Ames como el mejor libro del mundo]. GIBBS, "Introduction", p. 9. "As a practical exposition of what the word of God did and did not permit, illustrated by concrete cases, this is one of the most valuable sources of puritan morality. It was probably included with Ames's Medulla in the Divinity Catechetical that was taught on Saturdays". [Como una exposición práctica de lo que permitía y no permitía la palabra de Dios, ilustrada con casos concretos, esta es una de las fuentes más valiosas de la moralidad puritana. Fue probablemente incluido con la Médula de Ames en la Catequesis de Teología que se enseñaba los sábados]. Samuel Morison, Harvard College in the Seventeenth Century, p. 263, citado en GIBBS, "Introduction", p. 12.

34 " $[\mathrm{T}]$ the children of Israel should not need to go downe to the Philistines (that is, our Students to Popish Authors) to sharpen every man his share, his Mattocke, or his Axe, or his weeding Hooke, as it fell out in the extreame necessity of Gods people, I Sam 13. 20". [Los hijos de Israel no necesitarían descender a los Filisteos (esto es, nuestros estudiantes a los autores papistas) para que cada hombre afile la reja de su arado, o su azadón o su hacha o su hoz como le ocurrió al pueblo de Dios en extrema necesidad, I Sam 13:20]. Ames, Conscience with the Power and Cases Thereof, To the reader, s/p. Sobre este punto véase: Jan van VLIET, "The Moral Theology of William Ames A Look at the Structure and Thought behind William Ames", http://www.apuritansmind.com/William\%20Ames/VlietMoralTheologyAmes.htm (20/06/2009); y Jan van VLIET, "Gambling on Faith: a Holistic Examination of Blaise Pascal's Wager": Westminster Theological Journal, vol. 62 (2000), pp. 33-63, pp. 41, 42.

${ }^{35}$ AmEs, Conscience with the Power and Cases Thereof, To the reader, s/p. 
tinuas polémicas contra arminianos y papistas ${ }^{36}$ habían dejado poco tiempo para atender los problemas morales prácticos del día a día. A este respecto se confiaba en que la luz de la fe debía bastar para actuar conforme a la ley de Dios ${ }^{37}$. Fe y observancia son los dos pilares fundamentales. Por ello, una vez que ha tratado de la fe en The Marrow of Theology, Ames decide ocuparse de la segunda parte de la teología, la observancia, siguiendo el ejemplo pionero en el ámbito reformado del ya mencionado William Perkins. Ames consideraba a su maestro "the most grave Divine" y sigue sus pasos ${ }^{38}$, pero como expresa en las primeras páginas dedicadas al lector, Ames quiere también cubrir una carencia:

Observé que en diversas Iglesias, puras en ambas Doctrina y Orden, faltaba en gran medida esta enseñanza práctica, y que esta carencia era una de las causas principales de un gran abandono, o falta de cuidado en algunas obligaciones que conciernen de cerca la santidad y la vida crisitiana... Esta parte de la Predicación ha sido menos practicada en las Escuelas de los Predicadores, porque nuestros Capitanes eran forzados necesariamente a luchar siempre en el frente contra los enemigos para defender la fe y para purgar la base de la Iglesia; de modo que no

36 "Apart from his occasional anti-Arminian and anti-papal polemics, Ames in his teaching stressed practical theology... The goal was less controversy, more piety. Although the Dutch church was well skilled in controversial disputation through its habitual struggle with Arminians and papist, Ames the Puritan saw lacking a certain godliness and religion of the heart". [Al margen de sus polémicas ocasionales contra los Arminianos o contra el Papa, Ames en su enseñanza enfatizaba la teología práctica... El objetivo era menos controversia, más piedad. Aunque la iglesia holandesa estaba bien entrenada en la disputa de controversias por su lucha habitual con los Arminianos y los papistas, Ames el puritano veía que faltaba una cierta santidad y religion del corazón]. SpRUnGER, The Learned Doctor William Ames, p. 261.

37 " This part of Prophecie hath hitherto bin lesse practiced in the Schooles of the Prophets, because our Captaines were necessarily inforced to fight...They thought with themselves in the meane while (as one of some note writes) if we have that single and cleare eye to the Gospel, if in the house of our heart the candle of pure Faith be set upon a Candlesticke, these small matters might easily be discussed". [Esta parte de la Predicación ha sido hasta el momento menos practicada en las Escuelas de los Predicadores porque nuestros Capitanes eran forzados a luchar necesariamente...Ellos pensaban mientras tanto (como alguno de ellos de cierta importancia escribe) que si tenemos ese ojo único y claro puesto en el Evangelio, si en la morada de nuestro corazón la vela de la fe pura está puesta en su candelabro, estos pequeños asuntos podrían ser fácilmente discutidos]. Ames, Conscience with the Power and Cases Thereof, To the reader, s/p.

${ }^{38}$ Ibidem; e ibid., libro I, cap. I, 4, p. 2. VLIET, "The Moral Theology of William Ames. A Look at the Structure and Thought behind William Ames"; VLIET, "Gambling on Faith: a Holistic Examination of Blaise Pascal's Wager", pp. 41, 54, 55. 
podían sembrar y regar los Campos y Viñas como deseaban; como solía ocurrir en época de guerras abiertas ${ }^{39}$.

Como muestran estas palabras, Ames escribe impregnado de un ambiente beligerante, dominado por la prioridad de defenderse de los enemigos para sobrevivir y proteger la fe reformada. Ahora bien, en este contexto su obra Conscience with the Power and Cases Thereof se muestra como una contribución de otro cariz en esa tarea colectiva de compromiso y militancia de la que Ames se siente parte; una contribución invisible, complementaria a la de tomar las armas, que debía operar desde dentro de los individuos como una forma de entrenamiento íntimo en la tarea del autogobierno. Un planteamiento coherente con su visión militante del compromiso intelectual con la verdad y el saber ${ }^{40}$ y con su convicción de que la vida del cristiano es una guerra contra el reino de la oscu-

39 "I did observe that in divers churches, pure both for Doctrine and Order, this practicall teaching was much wanting, and that this want was one of the chiefe causes of the great neglect, or carelesseness in some duties which nearly concerne godliness, and a Christian life...This part of Prophecie hath...bin lesse practiced in the Schooles of the Prophets, because our Captains were necessarily inforced to fight always in the front against the enemies to defend the Faith, and to purge the floore of the Church; So that they could not plant and water the Fields and Vineyards as they desired; as it useth to fall out in time of hotte warres". AMES, Conscience with the Power and Cases Thereof, To the reader, s/p. Matthew Nethenus se hace eco de lo bien recibida que fue esta obra: "A rare work and for the many theological faculties of the Reformed universities unique!...The papal schools reproached us with this lack". [Un libro excepcional y para las muchas facultades de teología de las universidades reformadas ¡único!...Las escuelas papistas nos reprochaban esta carencia]. Gracias a la obra de Ames, añade Nethenus, los papistas ya no pueden decir que sus escuelas e iglesias sean superiores a las nuestras. NeTHENus, "Introductory Preface", p. 15.

40 "Let us not become the slaves of anyone, but, performing military service under the banner of free truth, let us courageously follow the truth that leads and calls away from the hallucinations of our elders, as they are men who have also been created in the image of Adam. Testing all things, retaining that which is good, let Plato be a friend, let Aristotle be a friend, but even more let truth be a friend". [No nos convirtamos en esclavos de nadie, sino que militando bajo el estandarte de la verdad libre, la sigamos con coraje apartándonos de las alucinaciones de nuestros antepasados, pues ellos también son hombres creados a la imagen de Adán. Comprobando todas las cosas, reteniendo lo que es bueno, deja que Platón sea un amigo, deja que Aristóteles sea un amigo, pero sobre todo deja que la verdad sea una amiga]. AMES, Technometry, tesis 77, pp. 106-107.

41 "The heretikes are to be resisted by every one that is godly, according to the calling and power which he hath received from God, it appears sufficiently from the nature of the thing: because all the godly are called to a Christian warfare, and are in their stations every one to oppose themselves to the kingdome of darknesse". [Que los herejes deben ser resistidos por todos los que son santos, de acuerdo a la llamada y el poder que han recibido de Dios, es algo que se explica suficientemente por la naturaleza del asunto: porque todos los santos están llamados a una guerra cristiana y están en sus puestos para oponerse al reino de la oscuridad]. AMES, Conscience with the Power and Cases Thereof, libro IV, cap. IV, 12, p. 12. 
ridad, "the kingdom of darkness" 41 - ese reino que da título a la cuarta parte del Leviathan de Thomas Hobbes (1588-1679) ${ }^{42}$ -

Pero la experiencia ha enseñado ampliamente, que mediante el descuido de este cultivo, un hambre de santidad se ha dado en muchos lugares...en la medida en que era necesario practicar el consejo de Nehemiah; a saber, que todos los hombres deberían dedicarse a este trabajo con una mano, sosteniendo en la otra una lanza o un dardo con el cual repeler la violencia de los enemigos ${ }^{43}$.

Mattew Nethenus habla sin ambages de William Ames como de un capitán militar capaz de "destruir la ciudadela" de los remonstrantes en el Sínodo de Dort, de vencer a Roberto Belarmino ${ }^{44}$, el Goliat de los Papistas, con su espada victoriosa (su obra Bellarminus Enervatus), o de enseñar a los "soldados de la teología" que iban a sucederle cómo tumbar y "decapitar" a estos filisteos, y expoliarles su campamento ${ }^{45}$. Ames comparte esta comprensión agresiva y llena de incertidumbres de la vida, que conmina a una actitud de vigilancia permanente. Una visión que se amalgama con facilidad con otras partes de su pensamiento.

En este punto parece reveladora su idea de eupraxia, que define las artes. Ames apoya una comprensión de las artes que disuelva la diferencia escolástica entre los saberes teóricos y los saberes prácticos, y a su vez entre el fabricar (poiesis) y el hacer (praxis) ${ }^{46}$. Para él, todas las artes consisten en un movimiento progresivo (génesis) o regresivo (análisis) que produce una $\mathrm{obra}^{47}$. La eupraxia (buena acción) remite tanto a la idea como al fin del arte ${ }^{48}$. Por ello, las artes

${ }^{42}$ HobBes, Leviathan, Parte 4, "Of the Kingdom of Darknesse", pp. 417ss. Véase Javier RoIz, El gen democratico, Trotta, Madrid, 1996, pp. 79ss.

43 "But experience hath taught at length, that through neglect of this husbandry, a famine of godlinesse hath followed in many places...insomuch that the counsel of Nehemiah had need to be practiced; namely that every man should labour in this worke with one hand, holding in the other a Speare or a Dart, whereby he may repell the violence of the enemies". AMES, Conscience with the Power and Cases Thereof, To the reader, s/p.

${ }^{44}$ Roberto Bellarmino (1542-1621), jesuita, es el autor de la obra en defensa del papado De Summo Pontífice. Hobbes dedica varias páginas del Leviathan a rebatir sus argumentos. HoBBes, Leviathan, cap. 42, pp. 378-402. Agradezco esta referencia a Jorge Loza-Balparda.

${ }^{45}$ Nethenus, "Introductory Preface", p. 17.

${ }^{46}$ AMEs, Technometry, tesis 32-34, p. 98; tesis 88-90, p. 108. Ver también la "Introducción" y el "Comentario" de Lee W. Gibbs sobre este punto en ibid., pp. 36-37, 141-142.

${ }^{47}$ AMES, Technometry, tesis 13, 19, pp. 95-96; tesis 32, p. 98.

${ }^{48}$ Ibid., tesis 9, p. 94 . Ver también ibid., tesis 60, p. 101. 
atienden al intelecto y a la voluntad, al conocimiento y a la acción ${ }^{49}$. El currículo formativo, señala Ames, debe atender al hombre completo; pues la dialéctica guía el intelecto, la teología, la voluntad, y las demás artes (la gramática, la retórica, las matemáticas y la física) orientan su movimiento ${ }^{50}$.

En todo ello hay un componente voluntarista que se acentúa cuando, por ejemplo, compara las reglas que "delinean" las artes con los decretos de un magistrado: "porque gobiernan ordenando, como los edictos de un magistrado, se llaman preceptos" ${ }^{51}$. Cualquier arte remite a una acción que se dirige a un fin y deja tras de sí una obra buena (euprattomenon) ${ }^{52}$.

Para no confundirnos, Ames matiza que la "obra" no tiene por qué ser algo externo y perceptible a los sentidos ${ }^{53}$. El ejercicio de cualquier disciplina siempre implica crear algo nuevo que antes no existía, pero ese algo no es necesariamente un objeto que pueda verse, tocarse u oírse. Así por ejemplo, cuando medimos la "obra" que realizamos es dejar las cosas medidas ${ }^{54}$. En este punto se ve claramente cómo se combinan en una única categoría el "fabricar" (poiesis) y el "hacer" (praxis).

La teología, como una de las seis artes de la enciclopedia amesiana, entra en este esquema; por ello tiene una parte teórica, que nos enseña sobre Dios a través de la revelación en las Sagradas Escrituras, y una parte práctica, que nos enseña sobre las virtudes para que podamos vivir bien ${ }^{55}$. En el planteamiento de Ames la parte práctica de la teología sustituye a la ética pagana y alumbra las otras dos disciplinas prácticas de la filosofía, la economía y la política. Estos dos saberes carecen de entidad propia como artes o ciencias: "Ya que cualquier pre-

${ }^{49}$ Ibid., tesis 10, 11, pp. 94-95.

${ }^{50}$ Ibid., tesis 117 , p. 115.

51 "Because they rule by commanding, like the edicts of magistrates, they are called precepts". Ibid., tesis 38, p. 99. Para Lee W. Gibbs esta descripción "revela que la comprensión voluntarista de Ames del gobierno y la ley está conectada estrechamente con la del mando de un soberano" ("reveals how closely Ames's voluntarist understanding of rule and law is connected with that of a sovereign's command") y lo relaciona con la siguiente idea de Ames expresada en The Marrow of Theology (libro 1, cap. 10, tesis 6-7, p. 111): “A law is made by commanding and forbidding. A law is established by promising and threatening"'. [Una ley se hace ordenando y prohibiendo. Una ley se establece prometiendo y amenazando]. Lee W. GIBBS, "Commentary", en ibid., p. 143.

${ }^{52}$ Ames, Technometry, tesis 32, p. 98.

${ }_{53}^{53}$ Ibid., tesis 34, p. 98.

54 “[M] easuring leaves measured things". [Medir deja las cosas medidas]. Ibid., tesis 33, p. 98.

${ }^{55}$ Ibid., tesis 111, 113, pp. 112-113. 
cepto de verdad universal que encontramos en la ética, la economía doméstica o la política mira debidamente hacia la teología"56.

Esta combinación tan característica de pensamiento y acción confluye en la biografía de Ames, apunta Sprunger, jugando con la urdimbre de su filosofía, como las dos mitades de una dicotomía ramista ${ }^{57}$.

\section{DISCERNIR Y DIRIGIR ${ }^{58}$}

La conciencia para William Ames se define como un acto; un juicio práctico elaborado por el entendimiento a partir de las leyes que la conciencia tiene dentro y que funcionan como un hábito ${ }^{59}$. De esta manera reproduce el modelo clásico, presente en Tomasso d'Aquino (1224-25-1274), en el que se reconoce que la conciencia tiene una doble naturaleza. Por un lado es un repositorio de leyes (synteresis o synderesis), y por otro, consiste en la aplicación de esas leyes a los casos concretos (syneidesis) ${ }^{60}$. Para ayudarnos a comprender los escritos de

56 "For any precept of universal truth that is found in ethics, household economy, or politics properly looks toward theology”. Ibid., tesis 92, p. 109. También: ibid., tesis 113-116, pp. 113-115.

57 "Like a Ramist dichotomy, his life was both theoretical religion speculation and vigorous exertion". [Como en una dicotomía ramista, su vida consistió tanto en especulación religiosa teórica como en ejercicio vigoroso]. A esto añade: "participation and action suited him much better than detached scholarship". [La participarción y la acción le iban mucho más que el estudio sin compromiso]. SPRUNGer, The Learned Doctor William Ames, p. 261.

${ }^{58}$ Para Ames son cuatro las funciones que cumple la conciencia; en cuanto a las cosas necesarias cumple dos acciones, obligar (to binde) e impeler a la práctica (to inforce to practice). En cuanto a las cosas indiferentes (middle and indifferent things), las acciones de la conciencia son también dos, discernir (to discern) y dirigir (to direct). AMES, Conscience with the Power and Cases Thereof, libro 1, cap. III, 1, 9, p. 6.

${ }^{59} \mathrm{Su}$ definición precisa es: "By Judgment therefore, in the definition of conscience, (I understand most properly with the best Shoolemen) an act of practical judgment, proceeding from the understanding by the power or meanes of a Habit". [Por juicio, por tanto, en la definición de la conciencia, entiendo de la forma más apropiada de acuerdo con los mejores maestros que es un acto de juicio práctico que procede a partir del entendimiento mediante el poder o los medios de un hábito]. Ibid., libro 1, cap. I, 6, p. 3. Más adelante, señala: "That synteresis out of which the proposition of this syllogism or the Law of conscience is taken, is most properly a habit of the understanding, by which we doe assent unto the principles of morall actions". [Que la synteresis de la que se extrae la proposición de este silogismo o la ley de la conciencia es más propiamente un hábito del entendimiento por el cual asentimos a los principios de las acciones morales]. Ibid., libro 1, cap. 2,1, p. 4.

${ }^{60}$ Ibid., libro 1, cap. 1, 10, p. 4. Edmund LeITES, "Casuistry and Character", en Edmund LeITES (ed.), Conscience and Casuistry in Early Modern Europe, Cambridge University Press, Cambridge, 1998, p. 124. Kenneth E. KIRK, Conscience and its Problems. An Introduction to Casuistry (1927), Longmans, Green and Co., London, New York, 1948, pp. 379-381. Sobre el origen de estos 
Ames y otros autores del siglo diecisiete, Norman Fiering observa acerca de sus antecedentes:

La mayoría de las nociones acerca de la conciencia que eran comunes en el siglo diecisiete ya habían sido elaboradas en la Edad Media...Los teólogos medievales, principalmente Buenaventura y Tomás de Aquino, tomaron de Aristóteles algunos conceptos psicológicos, y de la teoría moral estoica expresada en Cicerón y Séneca adoptaron algunas descripciones sustantivas de la conciencia, pero la teoría que se desarrolló, a pesar de sus raíces clásicas, fue esencialmente una creación de la Cristiandad, arraigada en los escritos de San Pablo y los primeros padres de la iglesia...El término "conciencia", una traducción del griego "syneidesis" se refería específicamente al juicio de la mente que concierne a la bondad o maldad moral de un acto particular. El conocimiento moral general que proveía los principios o normas de la conciencia era denominado "synteresis" (también "synderesis") ${ }^{61}$.

El juicio vinculado con la conciencia no consiste en una simple aprehensión de las cosas (juicio noético); es un juicio práctico que implica un asentimiento o una negación. Por ello es discursivo o dianoético, y su forma de operar es dialéctica a través de silogismos. En los juicios morales la ley funciona como premisa mayor; el caso concreto, como premisa menor (syneidesis o asunción). Y finalmente lo que llamamos juicio es la conclusión del silogismo $(\text { crisis })^{62}$. Juzgar, por tanto, consiste en contrastar el acto con la ley para deducir si aquel está

conceptos véase también: Robert A. GREenE, "Synderesis, the Spark of Conscience, in the English Renaissance": Journal of the History of Ideas, vol. 52, n. ${ }^{\circ} 2$ (1991).

61 "Most of the notions about conscience that were current in the seventeenth century had already been worked out in the Middle Ages...The medieval theologians, notably Bonaventure and Thomas Aquinas, borrowed from Aristotle some psychological concepts, and from stoic moral theory as expressed in Cicero and Seneca they took some substantive descriptions of conscience, but the developed theory, despite this classical roots, was essentially a creation of Christianity, rooted in the writings of St. Paul and the early church fathers...The term 'conscience', a translation from the Greek 'syneidesis', referred specifically to the judgment of the mind concerning the moral goodness or badness of a particular act...The general moral knowledge that provided the principles or norms of conscience was called 'synteresis' (also 'synderesis')". Norman FIERING, Moral Philosophy at Seventeenth-Century Harvard: A Discipline in Transition, University of North Carolina Press, Chapel Hill, 1981, pp. 52-53.

${ }^{62}$ AmEs, Conscience with the Power and Cases Thereof, libro 1, cap. 1, 10, p. 4. Sobre este punto véase: VLIET, "The Moral Theology of William Ames A Look at the Structure and Thought behind William Ames"; y VliET, "Gambling on Faith: a Holistic Examination of Blaise Pascal's Wager", pp. 54, 55. 
bien o mal, sin tomar en consideración la tradición, el sentido común o el qué dirán. El juicio moral tiene lugar en el contexto de una relación íntima entre cada individuo y Dios de modo que el entorno se desdibuja y carece de valor.

Las acciones y la regla deben compararse. Como el que dice la verdad no sabe si dice la verdad a menos que compare sus palabras con la cosa en sí misma, así el que actúa bien o mal tampoco lo sabe a menos que compare el hecho con la regla apropiada. La regla de esta prueba o juicio no tiene que ser nuestra razón natural, la costumbre de los demás o cosas por el estilo, sino la Ley o voluntad revelada de Dios. Ya que de otro modo no se respeta el juicio de Dios (al que mira la conciencia) sino el juicio de los hombres ${ }^{63}$.

Este tipo de razonamiento, en cuanto está guiado por las pautas de la dialéctica, es semejante al que rige universalmente en cualquier arte de la technometría. Al aplicarlo a asuntos morales, vemos que el juicio queda devaluado en discernimiento, una confusión sobre la que Arendt advertía al darse cuenta de que las normas morales pueden cambiarse con facilidad, y con poco cuentan en su haber en esos casos los ciudadanos si no se han formado en la capacidad de juzgar hechos sin precedentes; de pensar con sabiduría antes de actuar aún sin tener una norma a la que agarrarse ${ }^{64}$. En el mundo de Ames, sin embargo, de lo que se trata es de apuntalar con firmeza un código moral; no cabe pensar en cam-

63 "The actions and the rule must be compared together. For as he that speaketh the truth, knoweth not that he speaketh truth, unless he compares his speech with the thing it selfe; so he that doth well or ill, cannot know the same, unless he compare the fact with its proper rule. The rule of this trial or judgement, must not be our naturall reason, the custome of others or the like; but the Law, or revealed will of God; For otherwise Gods judgement is not respected (to which conscience looketh) but mens". Ames, Conscience with the Power and Cases Thereof, libro 1, cap. VI, 4. 2, p. 18.

${ }^{64}$ Hannah ARENDT, "Some Questions of Moral Philosophy": Social Research, vol. 61, n. ${ }^{\circ} 4$ (1994), pp. 739-764, 740. Hannah ARENDT, ¿Qué es la política?, Paidós, Barcelona, 2006, p. 54. "Los pocos individuos que todavía consiguieron distinguir el bien del mal se guiaron solamente por su propio juicio, libremente ejercido; no había normas que seguir y bajo las cuales los distintos casos particulares con los que se enfrentaban pudieran subsumirse. Tenían que decidir en cada ocasión de acuerdo con las circunstancias del momento, porque no había normas para unos hechos sin precedentes". Richard BERNSTEIN, "La responsabilidad el juicio y mal", en Richard BERNSTEIN y otros, Hannah Arendt: El legado de una mirada, Sequitur, Madrid, 2001, p. 46. 
biar las leyes que legítimamente deben regir las conciencias porque se trata de la voluntad de Dios ${ }^{65}$.

Trasmutando el juicio en discernimiento, el mundo interno se convierte en un ámbito dominado por los poderes ejecutivos de (i) la memoria, que almacena como un "registro" todas las acciones y sus intenciones ${ }^{66}$, del (ii) entendimiento que "discierne" y "dirige", y de (iii) la voluntad que provee a esa dirección de "poder" y "eficacia" ${ }^{67}$. Un mundo en perpetua vigilancia que excluye la letargia de la vida moral ${ }^{68}$.

Debemos emplear una continua vigilancia contra nuestros enemigos, pero especialmente contra nuestros enemigos espirituales. Nuestro Salvador ordena frecuentemente esta vigilancia en los Evangelios, pero especialmente en Marcos 13:33. Ten cuidado vigila y reza. 35. Vigila porque no sabemos etc. 37. Estas cosas que te digo a ti se las digo a todos los hombres, Vigila. Y San Pedro exhortaba de una manera parecida. Sed sobrios y vigilad, pues vuestro adversario el demonio como un león rugiente anda alrededor buscando a quien puede devorar, I Pedro 5:869.

65 "Conscience being referred to judgement, it is distinguished from the bare apprehension of truth. For conscience doth always suppose an assente that is firme and settled". [La conciencia en tanto que juicio se distingue de la mera aprehensión de la verdad. Ya que la conciencia siempre supone un asentimiento que es firme y estable]. AMES, Conscience with the Power and Cases Thereof, libro 1, cap. I, 2, p. 2.

${ }^{66}$ Ibid., libro 1, cap. VII, p. 14.

${ }^{67}$ Ibid., libro 1, cap. VII, 8, p. 17; libro 1, cap. III, 9, 10, 11, pp. 6-7.

${ }^{68}$ Para William Perkins, la conciencia tiene dos funciones, presta testimonio de los hechos y los juzga. En cuanto a su primera función, la conciencia actúa como un "notario" o un "registro" omnisciente que no duerme y al que nada se le oculta: "it hath alwaies the penne in his [its] hand, to note and record whatsoever is said or done". [Siempre tiene un bolígrafo en la mano, para anotar y registrar todo lo que se dice o hace]. William PERKIns, citado en FIERING, Moral Philosophy at Seventeenth-Century Harvard, p. 57.

${ }^{69}$ "We must use continual watchfulness against our enemies, but specially against our spirituall enemies. This watchfulness our Saviour commandeth often in the Gospell, but specially in Mar. 13.33. Take heed, watch and pray. 35. Watch therefore, for ye know not, \& c. 37. Those things that I say unto you, I say unto all men, Watch. And Saint Peter exhorteth in like manner, Bee sober, and watch: for your adversary the Divell as a roaring Lyon, walketh about seeking whom he may devoure, I Pet. 5. 8". William PERKINS, The Whole Treatise of Cases of Conscience (1651), edited with an introducion by Thomas F. Merrill, Nieuwkoop, B. de Graaf, 1966, libro III, cap. 2, Question I, p. 168. Énfasis en el original. Un razonamiento similar en: AMES, The Marrow of Theology, libro II, cap. II, 29, p. 229. 
Para funcionar bien, este mundo interno debe estar maduro. Al explicar que la voluntad puede actuar sin que haya un juicio anterior del entendimiento, Ames pone el ejemplo de los niños, a quienes les basta una aprehensión irreflexiva de las cosas para actuar (apprehensio objecti simplex), igual que les sucede a los dementes ${ }^{70}$. Esta apreciación nos da pie a entender que para Ames gobernarse es una tarea adulta, algo que podíamos prever al saber que el juicio es una tarea discursiva, y por ello, que no sirve para los que no saben hablar o expresarse con palabras; ni tampoco cuenta, por tanto, con el espacio inefable del self que asoma en estos versos de T. S. Eliot.

I see that my life was determined long ago

And that the struggle to escape from it

Is only a make-believe, a pretense

That what is, is not, or could be changed.

The self that can say "I want this, —or want that"-

The self that wills - he is a feeble creature;

He has to come to terms in the end.

With the obstinate, the tougher self; who does not speak

Who never talks, who cannot argue

$* * *$

The willing self can contrive the disaster

Of this unwilling partnership - but only flourish

In submission to the rule of the stronger partner ${ }^{71}$.

${ }^{70}$ Ames, Conscience with the Power and Cases Thereof, libro 1, cap. VII, 4, pp. 15-16. La misma reflexión aparece en John Leverett, citado en: FiERING, Moral Philosophy at SeventeenthCentury Harvard, p. 133.

${ }^{71}$ [Veo que mi vida fue determinada hace mucho tiempo/Y que la lucha por escapar de ella/ Es solo una fantasía, una ficción/Y que lo que es, no es, o podría cambiar/ El self que puede decir "quiero esto, —o quiero eso" - / El self que quiere —es una criatura débil;/ Al final tiene que llegar a un acuerdo/ Con el self obstinado y más fuerte; que no habla/ Que nunca conversa, que no sabe argumentar/ El self con voluntad puede arreglárselas con el desastre de su compañero sin voluntad - pero solo florece/ Sometiéndose al mando del compañero más fuerte]. The cocktail party de T. S. Eliot, citado en: Edgar Z. FriedenBerG, "The Ways of the Will, by Leslie H. Farber (Book Review)": Commentary, vol. 42, n. ${ }^{\circ} 4$ (1966), p. 144. 


\section{SACRALIZACIÓN Y PRIVATIZACIÓN DEL FORO INTERNO}

En esta visión puritana, la conciencia humana es un espacio íntimo y privado que conecta a cada individuo con la divinidad ${ }^{72}$. Es un espacio vedado a la intromisión de otras personas o artefactos humanos. Como en un tribunal, en el foro conscientiae se juzga, se absuelve y se condena. Pero a diferencia de los tribunales del foro externo, sólo Dios tiene acceso a él, y por ello, la conciencia solo está obligada por leyes que expresan la voluntad de Dios ${ }^{73}$. Ningún hombre puede juzgar la conciencia de otro. Se trata de un espacio opaco a la vista y por tanto cerrado para el conocimiento y la ciencia humana.

En estos juicios la conciencia acapara varios papeles. Actúa como ley (law or light), como testigo (witness) que da cuenta de los hechos y de las intenciones, como si se tratara de un registro (y por lo que es llamada booke or index), y como juez (judge $)^{74}$. Excluida la intervención de otras personas, estos juicios se convierten en actos privados ante Dios, como la confesión de Claudius en Ham$l e t^{75}$. Para explicarlo, Perkins había acudido a la etimología de conscience: "Scire, conocer, es de un hombre solo por sí mismo; y conscire es cuando al menos dos conocen alguna cosa secreta" ${ }^{\prime 7}$. De este modo, a través de la con-

${ }^{72}$ Norman Fiering señala sobre el precedente de Ames, William Perkins, autor de Discourse of Conscience (1596): “In reading William Perkins's theory of conscience one is immediately impressed by his determined construction of a sacrosanct personal inner space, separating the individual from earthly context and leaving only the privacy of the individual's relationship with God...One limitation of conscience that distinguished it from the eighteenth-century notion of moral sense, it should be noted, was its application only to the actions of the possessor. It was not a judge of the actions of others, although, presumable, synteresis could serve as a general criterion for judging the deeds of others". [Leyendo la teoría de la conciencia de William Perkins uno está inmediatamente impresionado por su resuelta construcción de un espacio interior personal sacrosanto, que separa al individuo del contexto terrenal y deja únicamente la privacidad de la relación del individuo con Dios... Una limitación de la conciencia que la distinguía de la noción de sentido moral del siglo dieciocho, debería anotarse, fue su aplicación solo a las acciones de su poseedor. No era un juez de las acciones de otros, aunque presumiblemente, synteresis podría servir como un criterio general para juzgar los actos de otros]. FIERING, Moral Philosophy at Seventeenth-Century Harvard, pp. 55-56.

${ }^{73}$ AMES, Conscience with the Power and Cases Thereof, libro 1, cap. II, 9, 13, 14, p. 5. Kirk subraya la analogía entre los tribunales civiles y el foro conscientiae en la Suma de Teología de Tommaso d'Aquino. KIRK, Conscience and its Problems, p. 380.

${ }^{74}$ AMEs, Conscience with the Power and Cases Thereof, libro, 1, cap. I, 9, p. 3; cap. VII, p. 14.

${ }^{75}$ William ShaKespeare, Hamlet, edición bilingüe del Instituto Shakespeare dirigida por Manuel Ángel Conejero Dionís-Bayer, Cátedra, Madrid, 2005, acto III, escena III, pp. 439-445.

76 "Scire, to know, is of one man alone by himselfe: and conscire is, when two at least knows some secret thing". Citado en FIERING, Moral Philosophy at Seventeenth-Century Harvard, p. 56. 
ciencia, el hombre y Dios saben juntos, son "compañeros en el conocimiento del mismo secreto" 77 .

El juicio retórico, que siempre es un acontecimiento público fuera del control de sus participantes, es suplantado aquí por una deliberación racionalista in foro interno que, frente a la generalidad de la ley, atiende a las particularidades de los casos, pero deseca sin embargo la contingencia del juicio en sí mismo.

Las leyes de los hombres, los pactos y las promesas deben obedecerse porque Dios quiere que así sea o por la voluntad divina que pueda haber en ellas. Pero por sí mismas no obligan a la conciencia ${ }^{78}$. Permitir que la conciencia esté obligada por los hombres es caer en idolatrí ${ }^{79}$. Esta relación íntima y sin intermediarios de cada hombre con Dios a través de su foro interno define una estructura horizontal en la que todos los hombres son su propio sacerdote, una idea luterana que perdura en la tradición reformada. Eliminar los intermediarios y las jerarquías es uno de los propósitos de la revuelta contra Roma; por ello desaparecen el sacramento del orden y de la confesión ${ }^{80}$. Católicos y protestantes coinciden en que la conciencia solo esté obligada por la ley de Dios; la diferencia es que los católicos aceptan que haya una jerarquía eclesiástica que sirva de intérprete de las Escrituras ${ }^{81}$. Tal vez intencionadamente, Ames subraya que los autores papistas son más expertos en hacer este tipo de obras de casuística porque las necesitan para enseñar a sus confesores ${ }^{82}$. Ames piensa que no se debe ir en contra de la propia opinión y en todo caso seguir la de otro hombre solo en virtud de su autoridad ${ }^{83}$. Puede entenderse que el fin de este catecismo es que cada hombre sepa como llevar a cabo por sí mismo la tarea de gobernarse.

\section{ERRANTE, DUBITANTE, ESCRUPULOSA}

La conciencia puede encontrarse en aprietos a la hora de juzgar los asuntos sobre los que tenga que tomar una decisión. Puede dudar de la ley que hay que aplicar

77 "Partners in the knowledge of one and the same secret". Ibidem.

${ }^{78}$ AmEs, Conscience with the Power and Cases Thereof, libro 1, cap. II, 11, 15, p. 5.

${ }^{79}$ Ibid., libro 1, chap. II, 12, p. 5; libro 1, "A Summary Collection of the former treatise", 15, p. 33.

${ }^{80} \mathrm{La}$ iglesia anglicana los mantiene, aunque no como sacramentos.

${ }^{81}$ FIERING, Moral Philosophy at Seventeenth-Century Harvard, p. 54.

${ }^{82}$ Ames, Conscience with the Power and Cases Thereof, To the reader, s/p. Ver también SPRUNGER, The Learned Doctor William Ames, pp. 155-156, 164.

${ }^{83}$ AMEs, Conscience with the Power and Cases Thereof, libro 1, cap. V, 4, p. 11. 
o de cómo hacerlo. Si duda sobre la ley a aplicar y yerra al hacerlo, lo importante es que la conciencia individual sea obedecida, a pesar de todo, pues ir en contra de la propia conciencia, aunque es posible, es ir en contra de la voluntad de $\operatorname{Dios}^{84}$. La conciencia de cada hombre es una proyección de la conciencia/voluntad de Dios ${ }^{85}$, "un pequeño Dios sentado en medio del corazón de los hombres" ${ }^{\text {" }}$.

Si la conciencia sabe qué ley debe aplicarse pero duda sobre cómo hacerlo, siente temor. Un escrúpulo, dice Ames, "es un temor de la mente sobre su práctica que molesta a la conciencia, como una piedrecilla que no puede sacar del zapato y hace daño al pie"87. La recomendación de Ames para sacarnos el escrúpulo de encima (to remove these scruples) es emplear la razón para proveernos de un conocimiento cierto que lo deje sin fundamento alguno, sin terreno en el que arraigar. "Pues la conciencia está más tranquila cuando tiene el conocimiento más cierto" $"$. A pesar de este gesto optimista, Ames reconoce a continuación que examinar los pensamientos y sustituirlos por razones contrarias, a veces no

84 " $[\mathrm{C}]$ onscience, though erroneous, bineth always so, that hee that doth against it, sinneth. The reason is, because he that doth against conscience, doth against Gods will: though not materially, and truly; yet formally, and by interpretation: because what the conscience doth declare, it declareth Gods will". [La conciencia, aunque sea errónea, obliga siempre, de modo que el que actúa en contra de ella, peca. La razón es porque aquel que actúa en contra de la conciencia, actúa en contra de la voluntad de Dios: aunque no de modo material y verdadero sí de un modo formal y de interpretación: porque lo que la conciencia declara, es declarado por la voluntad de Dios]. Ibid., libro 1, cap. IV, 6, p. 8.

85 "Conscience bindeth according as it is informed of the will of God: for in it selfe it hath the power of a will of God, and so stands in the place of God himself". [La conciencia obliga de acuerdo a que está informada de la voluntad de Dios: ya que en sí misma tiene el poder de una voluntad de Dios, así que está en el lugar de Dios mismo]. AMEs, Conscience with the Power and Cases Thereof, libro 1, cap. III, 2, p. 6.

86 "A little god sitting in the middle of men's hearts". Son palabras de William Perkins citadas en Lower Gallagher, Medusa's Gaze: Casuistry and Conscience in the Renaissance, Stanford University Press, Stanford, 1991, p. 8.

87 "Is a feare of the minde concerning its practice, which vexeth the conscience, as a little stone that cannot bee discerned in a mans shoe, paineth his foote". AMES, Conscience with the Power and Cases Thereof, libro 1, cap. VI, 1, p. 13. La comparación juega con la etimología de scrupule. Según el diccionario de María Moliner, escrúpulo procede de scrupulus, un guijarro pequeño, y en su primera acepción significa "Piedrecillla que se mete en el calzado". Según el DRAE escrúpulo es: "Duda o recelo que punza la conciencia sobre si algo es o no cierto, si es bueno o malo, si obliga o no obliga; lo que trae inquieto y desasosegado el ánimo". En su cuarta acepción significa: "China que se mete en un zapato y lastima el pie".

88 "For then is the conscience most quiet, when it hath most certaine knowledge". AMES, Conscience with the Power and Cases Thereof, libro 1, cap. VI, 1, pp. 13-14. 
funciona. Se impone entonces una solución menos pacífica: dejar de pensar sobre ello y actuar a pesar del escrúpulo ${ }^{89}$. Ames ofrece ejemplos prácticos para ilustrar este tipo de casos:

Toda la gente sabe que se debe rogar a Dios cada día; pero aún así alguien puede estar tan molesto por pensamientos impíos, que este escrúpulo puede surgir en un hombre: si debe o no rezar. Aquí no es siempre seguro examinar estos pensamientos, ni disputar mucho sobre esta cuestión, sino quitarse de encima este temor, como si dijéramos con violencia, y lanzarse a cumplir la obligación de rezar tan bien como se pueda ${ }^{90}$.

Esta suerte de decreto de la razón que establece la prohibición de pensar en algo se justifica con la idea de mantener acordonado el elemento extraño que queremos extirpar ${ }^{91}$. Ames es consciente de que pensar sobre un asunto puede hacer que se descontrole la situación. Al pensar sobre algo, dice Ames, se estimula la fantasía; de un pensamiento aflora una cascada de pensamientos

89 "Many scruples when they cannot well be taken away by some contrary reason, ought to be laid down as it were by violence, refusing to thinke or consider of them". [Muchos escrúpulos cuando no pueden quitarse con alguna razón contraria, deben ser apartados con violencia por decirlo así, rechazando pensar sobre ellos o tomarlos en consideración]. Ibid., libro 1, cap. VI, 3, p. 14.

90 "All people know that the name of God ought to be called upon daily; yet one may bee so vexed with impious thoughts, that this scruple may arise in a man, whether he ought to pray or not? Here it is not always a safe way to examine these thoughts, nor yet to dispute about this question long, but to throw away this feare, as it were by violence, and to fall upon the duty of prayer so well as one can". Ibidem.

${ }^{91}$ Ames aclara que se puede desobedecer el escrúpulo, porque el escrúpulo no es la conciencia. "If there is any man that is so molested through the consideration of his unworthinesse, that he dare scarce be so bold as to come to the Lords table, though he finde in himself true Faith and Repentance; he may and ought notwithstanding this scruple come to the Lords Supper. Neither is this to doe against Conscience, but according to Conscience. For a scruple is a rash feare and without any ground, and so cannot binde to doe according to it". [Si hay algún hombre tan molesto por la consideración de su falta de valía, que no se considera digno de acudir a la mesa del Señor, aunque encuentra en sí mismo verdadera fe y arrepentimiento; puede y debe a pesar de este escrúpulo acudir a la Cena del Señor. Ni es esto actuar contra la conciencia, sino de acuerdo con la conciencia. Ya que un escrúpulo es un miedo precipitado y sin ningún fundamento, y por tanto no puede obligar a actuar de acuerdo con él]. Ibid., libro 1, cap. VI, 4, p. 14. El escrúpulo aparece así como una anomalía, un elemento extraño que perturba y que hay que eliminar, un elemento que no está legitimado para tomar las decisiones. 
de los que ya es difícil hacerse cargo ${ }^{92}$. Sin embargo, si no le prestamos atención y no lo llevamos a la práctica, el escrúpulo deja de ser un problema ${ }^{93}$.

Puede que aquí Ames esté distinguiendo entre pensamiento y actividad menta ${ }^{94}$. Pensar sobre algo con insistencia y de forma repetitiva, con el espíritu lleno de temores y dudas, estaría en muchos casos más cerca de la actividad mental que del pensamiento genuino. Sin embargo, la solución que propone es sencilla. Sin considerar ningún matiz, confía en que uno mismo puede salir de ello con sus propias fuerzas.

Por debajo de estas recomendaciones para aliviar la incertidumbre y recomponer la situación interna de no saber qué hacer o sentirse paralizado, está la convicción voluntarista (y moderna) de que la voluntad es una facultad que goza de autonomía y tiene capacidad para dirigir el entendimiento hacia un objeto o retirar su interés de él; es decir, que tiene suficiente poder como para que podamos querer o no querer pensar sobre algo ${ }^{95}$, así como para dejar de querer hacer algo

92 "It helpeth much (if it may be conveniently) that the thinking upon those things be shunned, from which scruples may rise; for the fancy being once stirred, many thoughts arise, which cannot be suppressed againe, without great difficulty. As wee see in Tyles, that are linked together in order, if one happen to fall downe, the rest wil follow: and from hence are scruples multiplied in timorous consciences". [Ayuda mucho (si puede hacerse convenientemente) que se evite el pensamiento sobre esas cosas de las que pueden surgir los escrúpulos; ya que una vez estimulada la fantasía, surgen muchos pensamientos que no pueden suprimirse de nuevo sin gran dificultad. Como vemos en Tyles, que están enlazados entre sí en orden, si uno cae, el resto seguirá: y de ahí que los escrúpulos se multipliquen en las conciencias timoratas]. Ibid., libro 1, cap. VI, 5, p. 14.

93 "For so long as scruples are not actually applied, they are not troublesome". [Pues en la medida en que los escrúpulos no se apliquen de hecho, no son molestos]. Ibid., libro 1, cap. VI, 3, p. 14.

${ }^{94}$ Sobre el concepto de actividad mental, véase: RoIz, El experimento moderno, cap. 4.

${ }^{95}$ Así se deduce de: AMEs, Conscience with the Power and Cases Thereof, libro 1, cap. VII, 6, 7, p. 16. A este respecto, Norman Fiering señala: “Ames's analysis, we may remark, is an especially clear instance of both the Scholastic and the Agustinian theory of the will combining to break through the Thomist Scholastic structure...Ames was describing what later came to be allied the doctrine of attention. Descartes and a number of subsequent writers believed that the power to attend the mind to any particular object was an indication of freedom". [El análisis de Ames, podemos observar, es un ejemplo especialmente claro de una combinación de teoría escolástica y agustiniana que rompe con la estructura escolástica tomista...Ames estaba describiendo lo que más tarde vendría a ligarse con la doctrina de la atención. Descartes y un grupo de escritores posteriores creyeron que el poder de la mente de atender a un objeto particular cualquiera era un indicio de libertad]. Fiering, Moral Philosophy at Seventeenth-Century Harvard, pp. 122-123, n. 40. John Locke se muestra próximo a la psicología tradicional enseñada en Harvard en 1650 cuando escribe (Essay Concerning Human Understanding): "This, at least, I think evident, that we find in ourselves a power to begin or forbear, continue or end several thoughts of our minds, and motions of our bodies, barely by a choice or preference of the mind ordering, or as it were commanding, the 
que la conciencia ha juzgado como bueno ${ }^{96}$. Como sintetiza Norman Fiering, para Ames "cada vez que paramos o empezamos a pensar, lo cual es en sí mismo una acción, o a actuar externamente, no es necesario un juicio especial del intelecto, y sería absurdo asumir que lo es" ${ }^{\text {97 }}$. El poder de la voluntad se resume en que podemos querer Querer (volo Velle) ${ }^{98}$.

doing or not doing such a particular action, This power which the mind has thus to order...or to prefer...is that which we call the Will”. [Esto, al menos, creo que es evidente, que encontramos en nosotros mismos un poder para comenzar o dejar, continuar o terminar varios pensamientos en nuestras mentes y movimientos de nuestros cuerpos, apenas por una elección o preferencia de la mente que ordena, o manda por decirlo así, hacer o no hacer tal acción particular. Este poder que por tanto tiene la mente para ordenar...o para preferir...es lo que llamamos la Voluntad]. Citado en ibid., pp. 106-107.

${ }_{96}$ AMES, Conscience with the Power and Cases Thereof, libro 1, cap. VII, 5, p. 16. "It may be of incidental interest to note that Locke in his Essay Concerning Human Understanding considered the power to suspend action 'the great privilege of finite intellectual beings' and the only freedom that man has that makes any sense (Bk. II, chap. XXI, 53). Locke did not doubt, on the other hand, that will follows the last judgment of our reason, a fact that he called, as had Burgersdick 50 years earlier, a 'perfection of our nature' rather than a fault (Bk. II, chap. XXI, 48-49)'. [Puede ser de interés adicional anotar que Locke en su Ensayo sobre el Entendimiento Humano consideraba el poder para suspender la acción como 'el gran privilegio de los seres inteligentes finitos' y la única libertad que el hombre posee que tiene sentido (Libro II, cap. XXI, 53). Locke no dudó, por otra parte, que la voluntad sigue el último juicio de nuestra razón, un hecho que él llamaba, como lo había hecho Burgersdick cincuenta años antes, una 'perfección de nuestra naturaleza' más que un defecto (Libro II, cap. XXI, 48-49)". FIERING, Moral Philosophy at Seventeenth-Century Har$v a r d$, p. 124 , nota $\mathrm{n}^{\circ} 43$. Fiering hace un apunte interesante cuando reseña la aptitud de la doctrina amesiana para tomar decisiones cuando no se tiene mucho tiempo para ello: "However, even the sole ability to suspend action, we should note, is a considerable power for the will in ethical situations where timing may be of the essence". [Sin embargo, incluso la sola capacidad de suspender la acción, deberíamos apuntar, es un poder considerable de la voluntad en situaciones éticas donde el tiempo puede ser algo fundamental". Ibid., p. 124.

97 "Every time we stop or start to think, which is itself an action, or to act outwardly, a special judgment of the intellect is not necessary, and it would be absurd to assume that it is". Ibid., pp. 123-124.

98 "From hence we speak truly, and by the consent of all nations, say, I will Will". [De ahí decimos verdaderamente y con el consentimiento de todas las naciones quiero querer]. AMES, Conscience with the Power and Cases Thereof, libro 1, cap. VII, 8, p. 17. Para Leslie Farber, querer querer sería la apoteosis del voluntarismo que caracteriza nuestra época. Él la perfila como "la época de la voluntad desordenada" ("the age of disordered will") pues nos empeñamos en querer cosas que no pueden someterse a la voluntad: "We will to sleep, will to read fast, will to have simultaneous orgasm, will to be creative and spontaneous, will to enjoy our old age, and, most urgently, will to will". [Queremos dormir, queremos leer rápido, queremos tener orgasmos simultáneos, queremos ser creativos y espontáneos, queremos disfrutar nuestra vejez, y lo más urgente, queremos querer]. Leslie H. FARBER, "Will and anxiety" (1964), en The Ways of the Will, Selected Essays, Expanded Edition, New York, Basic Books, 2000, p. 109. Énfasis añadido. 
Ames se separa de la tradición intelectualista al refutar la idea de que la voluntad esté supeditada al intelecto, o como expresaban concretamente las tesis de Harvard College en el siglo diecisiete, que la voluntad esté determinada por el último juicio práctico del intelecto ("Voluntas determinatur ab ultimo Intellectus practici Judicio") $)^{99}$.

La voluntad, como le parece a muchos, no puede querer o no querer ninguna cosa, a menos que la razón primero juzgue lo que debe quererse o no quererse; ni puede elegir sino seguir el último juicio práctico del entendimiento y lo que la razón dicta que debe hacerse: y en consecuencia, la voluntad no puede mover contra la determinación de la conciencia. Para desentrañar esta cuestión [...¿icómo puede un hombre hacer algo en contra del dictado de su conciencia?...], deben establecerse estas conclusiones. Está tan claro que ningún hombre puede cuestionarlo...la voluntad no siempre sigue el juicio, aunque alguna vez siga esa orden a la que está sujeto, y que con frecuencia esté de acuerdo con el juicio ${ }^{100}$.

El mar de fondo de todo este debate entre posiciones intelectualistas y voluntaristas es la paradoja del comportamiento humano que pusieron en palabras de Ovidio y San Pablo:

"Porque lo que hago", observó Pablo, "no lo entiendo. Pues no hago lo que quiero, sino lo que aborrezo, eso hago" (Romanos 7:15). El conocido verso de Ovidio era citado con previsible frecuencia en los escritos morales: "Video meliora proboque; deteriora sequor" (Conozco y apruebo lo que es mejor, sigo lo que es peor $)^{101}$.

99 "The will is determined by the last judgment of the practical intellect". [La voluntad está determinada por el último juicio del intelecto práctico]. FIERING, Moral Philosophy at SeventeenthCentury Harvard, p. 113.

100 "The Will, as it seems to many, cannot will or nill any thing, unlesse reason have first judged it to be willed or nilled; neither can it choose but follow the last practical judgement, and that which reason doth dictate to be done: and by consequent, the will cannot move against the determination of conscience. For the unfolding of this question [...how a man can do anything against the dictate of conscience...?], these conclusions are to bee laid down. It is so cleare that no man can question it...the Will doth not always follow the Judgement, yet doth it ever follow that command whereto it is subject; and that agreeth oftentimes with Judgment...". AmEs, Conscience with the Power and Cases Thereof, libro 1, cap. VII, pp. 15- 17.

101 “'For that which I do,' observed Paul, 'I allow not: for what I would, that do I not, but what I hate, that I do' (Romans 7:15). Ovid's familiar line was quoted with predictable frequency in moral writings: 'Video meliora proboque; deteriora sequor' (I see and approve the better course; I follow the worse)". GREENE, "Synderesis, the Spark of Conscience, in the English Renaissance", p. 201. 
Este hecho de verse a uno mismo como otro sirvió para empezar a pensar sobre la voluntad como una facultad independiente del intelecto. Se empezó a considerar que si hacemos el mal es porque hay una fuerza capaz de rebelarse contra nuestro intelecto, con fuerza suficiente como para actuar por su cuenta. El reverso de este descubrimiento del poder de la voluntad, es la impotencia, la idea de que en ocasiones nos faltan fuerzas para llevar a cabo nuestros propósitos, la experiencia de "quiero-y-no-puedo" 102 . Ames probablemente se hace cargo de este anhelo cuando escribe:

Si hay una disposición constante de la voluntad en un hombre para consentir a esta instigación de la conciencia, juntas componen una conciencia moralmente buena ${ }^{103}$.

Sin embargo, la práctica nos muestra que conocer el bien no basta para llevarlo a cabo. Así pues, regresando al argumento de Ames sobre los escrúpulos, cuando se superan las posibilidades de la razón, el modo de dominarlos es ejercer cierta violencia sobre ellos ([they] ought to be laid down as it were by violence), evitando dedicarles pensamientos y actuando en su contra si no queda más remedio ${ }^{104}$. Aparece aquí la acción como coup d'état que interrumpe la indeterminación y resuelve la situación limpiamente ${ }^{105}$.

El resultado de esta victoria sobre los escrúpulos (que por los medios empleados, sería una victoria militar) y de las sucesivas, si se adopta como costumbre este modo de proceder ("mediante la costumbre de actuar contra tales

${ }^{102}$ Hannah ARENDT, La vida del espiritu, Paidós, Barcelona, 2002, pp. 296ss.

103 "If there be a constant disposition of will in a man consenting to this instigation of conscience, they do together make up a conscience morally good". AMES, Conscience with the Power and Cases Thereof, libro 1, cap. III, 8, p. 6.

${ }^{104}$ Ibid., libro 1, cap. VI, 4, p. 14.

${ }^{105}$ La expresión de coup d'état es de Henry Bergson. ARENDT, La vida del espíritu, p. 334. Este modo de proceder parece bastante congruente con el planteamiento posterior del filósofo y psicólogo pragmatista William James (1842-1910): “Action seems to follow feeling, but really action and feeling go together; and by regulating the action, which is under the more direct control of the will, we can indirectly regulate the feeling, which is not". [La acción parece seguir el sentimiento, pero realmente la acción y el sentimiento van juntos; y mediante la regulación de la acción, que está bajo el control más directo de la voluntad, podemos regular indirectamente el sentimiento, que no lo está]. William JAMES, The Gospel of Relaxation, http://www.des.emory.edu/mfp/jgospel.html (6/02/2009). 
escrúpulos"), es una conciencia que se hace cada vez más fuerte (more strong and setled, firmior) $)^{106}$. Lo contrario de una conciencia "timorata"107.

\section{LA LIBERTAD COMO ELECCIÓN}

Aunque se eluda hablar de gobierno del individuo, el lenguaje empleado por Ames y sus contemporáneos para estudiar el alma y la moral es claramente político $^{108}$. El foro interno es un lugar donde se juzga, donde se toman decisiones y donde se da la orden de ejecutar esas decisiones. Para la mentalidad puritana del siglo diecisiete los poderes del foro interno se organizan como en una monarquía dominada por la voluntad; la voluntad es la "reina" que toma las decisiones y el intelecto es el "consejero" o el "piloto" que la guía y auxilia en esta tarea ${ }^{109}$.

106 "Through custome of doing against such like scruples". AmEs, Conscience with the Power and Cases Thereof, libro 1, cap. VII, 3, p. 14.

${ }^{107}$ Ibid., libro 1, cap. VII, 2, p. 14.

${ }^{108}$ Esto no es algo exclusivo del siglo diecisiete. En una obra contemporánea de casuística nos encontramos igualmente con una reflexión teológica que hace suyos conceptos políticos. Además de la inmediata analogía de la conciencia con el funcionamiento de un tribunal, una analogía de raíz escolástica (KIRK, Conscience and its problems, p. 36), Kenneth E. Kirk señala, por ejemplo, que los escrúpulos proceden como una "guerrilla" para inhibir la acción (ibid., p. 25); o que personificar la conciencia como si fuera algo distinto de nosotros mismos equivale a considerarla una tirana y a identificarnos con aquellas motivaciones inferiores contra las que pelea nuestro self más elevado ("those lower motives against which my higher self [e.g. conscience] is in arms") (ibid., pp. 56-57). A propósito de este asunto, no es difícil ver que cuando Kirk aconseja no personificar la conciencia como otro sino identificarnos con ella ("Conscience is just myself") y asumir la resolución de los problemas morales "in a moral way", es decir, mediante la razón (ibid., p. 57), nos está aconsejando sustituir ese modelo de guerra interna y dominación dictatorial por una solución política; su idea sería que "my best self" gobierne "my whole self", que él entiende como un entramado conflictivo de intereses ("a complex of constesting and only half-harmonised interests") (ibid., p. 56).

Es de notar que Norman Fiering trata las doctrinas voluntaristas e intelectualistas como planteamientos psicológicos. No en vano, sus referencias contemporáneas sobre el estudio de la voluntad y su relación con el intelecto son psicoanalistas, en concreto Sigmund Freud y Leslie Farber. Norman Fiering, "Appendix. A Note on the Problem of Will in the Twentieth Century", en Moral Philosophy at Seventeenth-Century Harvard, pp. 303-305.

${ }^{109}$ Para John Flavel (1627-1691) (Pneumatología, 1685), "The will, too, is 'a very high and noble Power of the Soul', to which the understanding bears the same relation 'as a grave Counsellor doth to a great Prince". [La voluntad, también, es "un Poder del Alma muy elevado y noble" con el que el entendimiento tiene la misma relación que "un grave Consejero con un gran Príncipe"]. Citado en: Fiering, Moral Philosophy at Seventeenth-Century Harvard, p. 127. 
Otros autores como John Leverett, futuro presidente de Harvard College, prefieren hacer una analogía con la Trinidad:

Cuando hago algo intra, la voluntad es el comienzo del acto, y ella como una Reina primero ordena: quiero que se haga esto o eso; entonces la razón piensa en los medios para este fin, y cuando estos se han encontrado, el poder lleva la cosa a la práctica; y de ahí se hace una similitud con el misterio de la Trinidad; que el Padre podría ser comparado con la voluntad, pues es el comienzo de la acción; el Hijo con la razón porque a él le es dado la administración de las cosas, y aquí está la sabiduría de su padre; el Espíritu Santo con el poder de ejecutar las cosas ya que es el perfeccionador de todos los Actos, y es llamado el poder del Altísimo ${ }^{110}$.

Las anotaciones de los estudiantes de Harvard, como lo era en su momento Leverett, delatan el magisterio de Ames; así, por ejemplo, en 1653 John Stone dejó escrita una comprensión de la voluntad muy reveladora bajo el título de "An explication of certain rules in Logick":

Después de que un hombre entiende una cosa completamente, la elige o la rechaza; el entendimiento encuentra más cosas y se las presenta a la voluntad (que está establecida como una reina) para saber lo que complace a su majestad; algunos se preguntan cual es la facultad superior, si la voluntad o el entendimiento, pero la voluntad es la suprema, porque tiene la capacidad de emitir y determinar el voto, todo lo demás son para esto, los sentidos externos son para los internos, y los internos para el entendimiento (de acuerdo a la regla de que nihil est in intellectu quod non prius fuit in sensu) y el entendimiento es para la voluntad, como un antecedente para sus acciones, como un piloto que la guía y la dirige...y como un acompañante para llevar la vela delante de ella: y ambos el entendimiento y la voluntad [son] para Dios; la voluntad está por encima del poder de cualquier causa segunda, y no puede ser compelida por ninguna; los hombres pueden forzar la mano a trabajar y los pies a caminar y la lengua a confesar, pero no pueden [forzar] a la voluntad a actuar porque el acto más apropiado de la voluntad es elegir; es una contradicción decir que puede ser compelida a elegir...la voluntad tiene el poder y el dominio

110 "When I do any thing intra, the will is the beginning of the act, and shee like a Queen first commands, I will have this or that done; then reason thinks of meanes to this end, and those being found, the power doth put the thing in practice; and hence is drawn a similitude to express the mistery of the Trinity; that the Father should be compared to the will, for that he is the beginning of the action; the Son Reason for to him is given the dispensation of things, and here is the wisdom of his father; the HG to the power of executing things for he is the perfecter of every Act, and is called the power of the most high". John LeVeretT, Common Place Book (c. 1680), in the Massachusetts Historical Society, citado en ibid., pp. 129-130. 
sobre sus propias acciones: voluntas prout uti voluntati. Un hombre puede querer querer ${ }^{111}$ y elegir elegir y esta libertad es tan inseparable de la voluntad como lo es la luz del sol ${ }^{112}$.

Para esta mentalidad, la libertad consiste en elegir, que es un acto de la voluntad. Considerando la relación entre voluntad e intelecto, Ames había explicado que la libertad radica en el intelecto, que juzga y propone a la voluntad lo que es bueno, pero formalmente está en la voluntad, que es capaz de moverse a sí misma y a las demás facultades ${ }^{113}$, y como decíamos, goza de autonomía para orientar al intelecto e iniciar o suspender la acción. Lo único que la voluntad necesita del intelecto es la comprensión inicial o inmediata de las cosas, pues no se puede querer algo que se desconoce ${ }^{114}$.

Aunque la voluntad sea determinada por el entendimiento en lo que concierne a la especificación de la cosa a querer, porque no quiere nada sino aquello que el entendimiento ha aprehendido primero; sin embargo respecto al ejercicio o acto de querer, se mueve a sí misma y al entendimiento con el resto de las facultades ${ }^{115}$.

111 Vide supra nota 98.

112 "After a man understands a thing fully, he chuses or refuseth; the understanding finds out more things and presents to the will (which setts as queen) to know her majesties pleasure; some question whether the will or the understanding be the superior faculty, but the will is the supreame, for it hath the casting and determining vote, all the rest are for this, the outward senses are for the inward, and the inward for the understanding (according to that rule nihil est in intellectu quod non prius fuit in sensu) and the understanding is for the will, as an antecedent of her actions, and as a pilote to guid and direct her... and as an attendant to beare the candle and lanthorne before her: and both understanding and will for god; the will is above the powere of any second cause, it cannot be compelled by any; men may force the hand to work and the feet to walk, and the tongue to confesse, but they cannot the will to act because the proper act of the will is to elect; it is a contradiction to say it may be compelled to elect...the will hath the power and dominion over its own actions: voluntas prout uti voluntati. A man can will to will and chuse to chuse, and this liberty is as inseparable from the will as light from the sun". Citado en FIERING, Moral Philosophy at Seventeenth-Century Harvard, p. 128.

113 Ames, Conscience with the Power and Cases Thereof, libro 1, cap. VII, 7, p. 16.

114 "No man was ever knowne to desire what he no waies knew". AMEs, Conscience with the Power and Cases Thereof, libro 1, cap. VII, 3, p. 15. "Ignoti nulla cupido", en la version latina (La edición consultada es: Giuilielmi AMESII, De conscientia et ejus jure, vel casibus, libre quinque, editio nova, Oxonii, Typis Gulielmi Hall, 1659, p. 19). Esta es una frase de Ovidio, también empleada por Leverett. FIERING, Moral Philosophy at Seventeenth-Century Harvard, p. 132, nota 57.

115 "Though the will be determined by the understanding in regard of the specification or kinde of thing to be willed, because it willeth nothing but that which the understanding hath first apprehended; yet in regard of exercise or act of willing, it moveth both it selfe, and the understanding with the rest of the faculties". AMEs, Conscience with the Power and Cases Thereof, libro 1, cap. VII, 7, p. 16 . 
Dada esta preeminencia, "la voluntad es el verdadero sujeto de la teología ya que es el verdadero comienzo de la vida y de la acción moral y spiritual" 116 .

Ahora bien, la voluntad tiene autonomía respecto de las demás facultades espirituales, pero no respecto de Dios ${ }^{117}$. La voluntad puede abrir un ojo, o abrir la mano, pero no puede abrir el corazón, decía John Flavel ${ }^{118}$. Ante la voluntad divina o las tentaciones del diablo, la voluntad humana es impotente y por ello necesita del auxilio de la gracia. Si la voluntad siguiera los dictados del intelecto, no habría pecados, solo habría errores intelectuales. El problema es que la voluntad a veces se rebela contra el intelecto, y como le sucede a la Medea de Ovidio, a pesar de conocer y aprobar el bien, hace el mal (Video meliora proboque; Deteriora sequor). El voluntarismo de Ames está asociado así a sus convicciones religiosas y sirve para consagrar el poder de Dios que actúa allí donde el hombre flaquea:

Si la Voluntad sigue necesariamente al Entendimiento entonces en la Regeneración la Voluntad misma no necesita ser internamente renovada por la gracia: ya que la iluminación del Entendimiento sería suficiente. Pero esto es repugnante a la Fe y la santidad ${ }^{119}$.

\section{CONCLUSIÓN}

Para William Ames, el pensamiento está siempre vinculado a la acción. Debe servir para algo, responder a una necesidad de la vida humana. Por eso la teología

116 "The will is the true subject of theology since it is the true beginning of life and of moral and spiritual action". AMEs, The Marrow of Theology, libro II, cap. II, 7, p. 224.

${ }^{117}$ Fiering señala que hay que hacerse cargo de la diferencia entre la libertad de la voluntad de la que habla Luis de Molina (1535-1600) y la libertad agustiniana que subordina la voluntad a la influencia de Dios o del Diablo. Fiering, Moral Philosophy at Seventeenth-Century Harvard, p. 137. Ver también, ibid., p. 118. Ames se separa en este aspecto del jesuita Francisco Suárez (15481617), que sigue la doctrina molinista de la libertas indifferentiae: "the detachment of the will from the intellect as argued by Suarez undoubtedly provided support for Ames. But the Protestant emphasis on the radical dependence of the will on God is not found in Suarez, who considered this idea a Lutheran heresy". [La indiferencia de la voluntad respecto del intelecto como la argumenta Suárez indudablemente proporcionó un soporte para Ames. Pero el énfasis protestante en la dependencia radical de la voluntad en Dios no se encuentra en Suárez, quien consideró la idea una herejía luterana]. Ibid., p. 124. Ver también, ibid., p. 120.

${ }^{118}$ Ibid., p. 127.

119 "If the Will do necessarily follow the Understanding, then in Regeration the Will it selfe need not be internally renewed by grace: for the inlightening of the Understanding would be sufficient. But this is repugnant to Faith and Godlinesse". AmEs, Conscience with the Power and Cases Thereof, libro 1, cap. VII, 7, p. 17. 
no puede quedarse en la pura especulación acerca de los preceptos de la fe, sino que debe desarrollar su parte práctica. Se trata de gobernar el alma de un cristiano. Esto tiene un sentido muy positivo pues se opone a la inflación de pensamiento del escolasticismo de las escuelas medievales.

Ames se refiere a la importancia del hacer, de que los proyectos se ejecuten, que las deliberaciones no se queden sobre el papel. Todas las disciplinas son comparables a la labor de un artesano que imagina el diseño de un objeto y dilucida el modo de elaborarlo con el ánimo puesto en fabricarlo ${ }^{120}$. Solo una vez fabricado se podría decir que el artesano es artesano ${ }^{121}$. Para Ramus la dialéctica tenía sentido si servía para elaborar un razonamiento y para comprender, mediante el análisis, el razonamiento ajeno. Los preceptos de la dialéctica, en este sentido, debían ser estrictamente aquellos que la experiencia demostrara que son válidos, aquellos que nos aclaren el camino al conocimiento, no que lo oculten o lo dificulten. Debatir sobre los preceptos mismos enredándose en una interminable espiral de detalles vacíos carece de sentido. Las reglas del arte sólo pueden cuestionarse tras haber practicado con ellas.

Asociar el pensamiento a la acción cotidiana permite que aquél no se pierda en el cielo como un globo hinchado de propósitos impotentes. El vínculo con las cosas concretas del día a día da realismo al pensamiento, y ofrece garantías a las personas de que sus esfuerzos no van a quedar disueltos en la frustración. Evita que esas personas queden abandonadas y relegadas a (mal)vivir entre fantasmas y ficciones.

Sin embargo, el tropo de la guerra que está tan inserto en el calvinismo impide pararse a pensar. Ante la urgencia de lograr la supervivencia en un mundo asediado por constantes peligros internos ${ }^{122}$ y externos ${ }^{123}$, el cristiano debe man-

${ }^{120}$ GIBBS, "Introduction”, p. 37.

${ }^{121}$ Petrus Ramus, Dialectique (1555), Texte modernisé par Nelly Bruyère, Vrin, Paris, 1996, p. $82-83$

${ }^{122} \mathrm{El}$ gran temor es que el pecado se adueñe del alma. Enfrentarse a las tentaciones, que nunca desaparecen, es algo muy parecido a librar un combate con uno mismo: "It is very difficult to overcome temptations because that in this corruption of our nature no man fights with all his strength against any temptation, but partly for it, and against himself. A believer in temptation is as a Kingdome divided within it self'. [Es muy difícil sobreponerse a las tentaciones porque en esta corrupción de nuestra naturaleza ningún hombre lucha con toda su fuerza contra alguna tentación, sino en parte por ella y contra sí mismo. Un creyente tentado es como un reino dividido]. AMES, Conscience with the Power and Cases Thereof, libro II, XXIII, p. 52. En este punto Ames está citando a William Paris - Guillaume de Auvergne (1190-1249) — obispo de París del siglo trece.

${ }^{123}$ Para Calvino, "todo cuanto nos rodea, no solamente es sospechoso, sino que casi abierta 
tenerse alerta y dispuesto para un ataque inminente. El alma del cristiano a duras penas puede encontrar reposo sabiendo que "el diablo nunca duerme" 124 . Por ello tiene mucho sentido para los puritanos contar con catecismos y compendios que ofrezcan respuestas y ipreguntas! ${ }^{125}$, y que pueden aprenderse de memoria e incluso recitarse ${ }^{126}$. Este modo de instrucción muestra a las claras cómo en la amalgama entre pensamiento y acción la balanza se descompensa del lado del hacer. Así mismo, el pensamiento se devalúa con la correspondiente invasión a la letargia. El temor a no estar alerta, a que nos pillen desprevenidos, que puede significar un riesgo letal ${ }^{127}$, arrasa con la frágil ecología democrática del mundo interno. No queda un lugar donde puedan cobijarse ni la invención y ni el juicio entendidos de un modo retórico.

No quiere esto decir que el pensamiento quede anulado y todo se resuelva de un modo dogmático. Pero hay ciertas cuestiones básicas que no se pueden

mente nos está amenazando y no parece sino que está intentando darnos muerte". Juan CALVINO, Institución de la Religión Cristiana, trad. de Cipriano Valera (1597), reeditada por Luis de Usoz y Río (1858), 2 vols., Visor, Madrid, 2003, libro I, cap. XVII, 10, vol. I, p. 145.

124 "Car le diable ne dort jamais". Jena MorÉLY, Traicté de la discipline \& police chréstienne, Ian de Tournes, Lyon, 1562, p. 18. Jean CALVIN, Catéchisme, c'est à dire le formulaire d'instruire les enfants en la Chrestiente, faict en maniere de dialogue, ou le Ministre interrogue, et l'enfant respond, Chez Émile Beroud, Genève, 1553, p. 10.

${ }^{125}$ Calvino aprecia este método para instruir a los niños. CALvino, Institución de la Religión Cristiana, libro IV, cap. XIX, 13, vol. II, p. 1149. Él mismo escribió el Catecismo de Ginebra: CALvin, Catéchisme.

126 "Edwin Oviatt has pointed out that at the Collegiate School in Connecticut, Ames's Cases of Conscience were sometimes recited by the students in Latin on Saturdays, and that at the close of 1726 'Wollebius' 'Theology', and Ames' 'Theses and his Medulla', and the 'Assembly's Shorter Catechism' in Latin were recited on week days, and Dr. Ames 'Cases of Conscience' on Sundays". [Edwin Oviatt ha señalado que en el Collegiate School en Connecticut, la obra Cases of Conscience de Ames era a veces recitada por los estudiantes de Latín los sábados, y que a finales de 1726 la Teología de Wollebius y las Tesis y la Médula de Ames y el Catecismo Abreviado de la Asamblea en latín eran recitados los días de la semana, y los Cases of Conscience de Ames los domingos]. GiBBS, "Introduction", p. 12.

127 "Tened en cuenta a nuestro enemigo y el peligro que por él corremos, nunca estaremos en lugar secreto ni seguro". Thomas TAYLOR, Christ's Combat and Conquest, Londres, 1618, p. 20, citado en Micahel Walzer, La revolución de los santos: Estudio sobre los orígenes de la política radical, Katz, Madrid, 2008, p. 296. Walzer expone de forma excelente el mito puritano de la guerra permanente. La guerra interna contra los manejos del diablo y externa contra los enemigos de la verdadera iglesia se convierte en una forma de vida que asimila todas las actividades, sea la política o la vida de la iglesia, a la lógica de la guerra y a todos los cristianos con combatientes. Veáse ibid., cap. 8. Para Thomas Taylor: "La condición del hijo de Dios es la de militar en esta vida". Y así mismo: "Todas las clases de hombres son guerreros, algunos están luchando por la expansión de la religión y otros contra ella". Citado en ibid., p. 296. 
cuestionar, puntos ciegos que constituyen un consenso básico con los demás y con nosotros mismos. Son compartimentos que deben quedar sellados para seguir mirando hacia delante.

Por otra parte, este modelo de preguntas y respuestas, y ese gusto por ordenar y enumerar los argumentos hasta llegar al flamante (ego) respondeo ${ }^{128}$ nos recuerda que las innovaciones que aporta el calvinismo a los modos de pensamiento y de gobierno en Occidente están empapados de la tradición escolástica, cuya pedagogía se basaba en las disputas y en la resolución de cuestiones ${ }^{129}$. Esta pervivencia es algo que conviene reconsiderar. El principio de identidad que es básico en la Metafísica de Aristóteles ${ }^{130}$, y en la Summa Teologicae de Aquino, lo es también para Hobbes ${ }^{131}$.

Tomando a William Ames como referencia, vemos que el gobierno del individuo es un tema principal en el puritanismo. Aquí es tratado desde un punto de vista moral, como un asunto ligado a la fe que queda expulsado de los asuntos públicos. Hasta hoy la ciencia política ha temido acercarse a este tema y ser tachada por ello de entrometida.

En realidad lo que está en juego es la centralidad de la voluntad en el gobierno de cada uno. Habida cuenta de las compulsiones que a menudo ensombrecen nuestra vida en común, parece que esta es una tarea que no puede eludir la teoría política de la democracia. Una democracia "pacífica, trabajadora, cotidiana" 132 que recale fuera y también, sobre todo, dentro de los ciudadanos. No como un implante piadoso cargado de autoritarismo, sino como un objeto benigno ${ }^{133}$ que desde dentro afloje las bridas del pensamiento, y en el día a día nos acompañe, apacigüe y nos vincule a nuestros vecinos.

${ }^{128}$ Una fórmula que Hobbes emplea reiteradamente en Leviathan como "I answer". HoBBeS, Leviathan, cap. 17, p. 119; cap. 32, p. 257; cap. 42, pp. 401, 402; cap. 44, p. 426; cap. 45, p. 442. Agradezco a Jorge-Loza Balparda estas referencias.

${ }^{129}$ En Harvard y Yale seguían empleándose durante el siglo diecisiete. GIBBS, "Introduction", pp. 22, 42 .

${ }^{130}$ ARIstóteles, Metafisica, trad. de Valentín García Yebra, Gredos, Madrid, segunda edición, 1982, libro IV, 3, 1006a, líneas 10-12. El libro IV desarrolla una demostración de este principio y una refutación de los planteamientos de otros filósofos que lo contradicen.

${ }^{131}$ HobBes, Leviathan, cap. 3, p. 24; cap. 12, p. 84, cap. 46, p. 467. Agradezco a Jorge-Loza Balparda estas referencias.

${ }^{132}$ RoIz, La recuperación del buen juicio, p. 41.

${ }^{133}$ El concepto de "objeto bueno" lo tomo de Melanie KLEIN, "Nuestro mundo adulto y sus raíces en la infancia" (1959), en Envidia y gratitud, Aguilar, Buenos Aires, 2008, pp. 308, 310. 